\title{
A Holocene record of Pacific Decadal Oscillation (PDO)-related hydrologic variability in Southern California (Lake Elsinore, CA)
}

\author{
M. E. Kirby $\cdot$ S. P. Lund $\cdot$ W. P. Patterson • \\ M. A. Anderson • B. W. Bird • L. Ivanovici • \\ P. Monarrez $\cdot$ S. Nielsen
}

Received: 13 August 2009/ Accepted: 4 July 2010/Published online: 17 July 2010

(C) The Author(s) 2010. This article is published with open access at Springerlink.com

\begin{abstract}
High-resolution terrestrial records of Holocene climate from Southern California are scarce. Moreover, there are no records of Pacific Decadal Oscillation (PDO) variability, a major driver of decadal to multi-decadal climate variability for the region, older than 1,000 years. Recent research on Lake Elsinore, however, has shown that the lake's sediments hold excellent potential for paleoenvironmental analysis and reconstruction. New 1-cm contiguous grain size data reveal a more complex Holocene climate history for Southern California than previously recognized at the site. A modern comparison between the twentieth century PDO index, lake level change, San Jacinto River discharge, and percent sand suggests that sand content is a
\end{abstract}

M. E. Kirby $(\bowtie) \cdot$ L. Ivanovici · P. Monarrez ·

S. Nielsen

Department of Geological Sciences, California State

University, Fullerton, Fullerton, CA 92834, USA

e-mail: mkirby@fullerton.edu

L. Ivanovici

e-mail: romanianprincess84@hotmail.com

P. Monarrez

e-mail: paydrowk@yahoo.com

S. Nielsen

e-mail: sniel002@fiu.edu

S. P. Lund

Department of Earth Sciences, University of Southern

California, Los Angeles, CA 90089, USA

e-mail: slund@usc.edu reasonable, qualitative proxy for PDO-related, hydrologic variability at both multi-decadal-to-centennial as well as event (i.e. storm) timescales. A depositional model is proposed to explain the sand-hydrologic proxy. The sand-hydrologic proxy data reveal nine centennial-scale intervals of wet and dry climate throughout the Holocene. Percent total sand values $>1.5$ standard deviation above the 150-9,700 cal year BP average are frequent between 9,700 and 3,200 cal year BP $(n=41)$, but they are rare from 3,200 to 150 cal year BP $(n=6)$. This disparity is interpreted as a change in the frequency of exceptionally wet (high discharge) years and/or changes in large storm activity. A comparison to other regional hydrologic proxies (10 sites) shows more then

W. P. Patterson

Department of Geological Sciences, University of Saskatchewan, Saskatoon, SK S7N 5E2, Canada e-mail: Bill.Patterson@usask.edu

M. A. Anderson

Department of Environmental Sciences, University

of California, Riverside, Riverside, CA 92521, USA

e-mail: michael.anderson@ucr.edu

B. W. Bird

Byrd Polar Research Center, The Ohio State University,

Columbus, $\mathrm{OH} 43210$, USA

e-mail: bird.102@osu.edu 
occasional similarities across the region (i.e. 6 of 9 Elsinore wet intervals are present at $>50 \%$ of the comparison sites). Only the early Holocene and the Little Ice Age intervals, however, are interpreted consistently across the region as uniformly wet ( $\geq 80 \%$ of the comparison sites). A comparison to two ENSO reconstructions indicates little, if any, correlation to the Elsinore data, suggesting that ENSO variability is not the predominant forcing of Holocene climate in Southern California.

Keywords PDO - Grain size · Holocene ·

Lake sediment $\cdot$ Southern California

\section{Introduction}

Southern California is home to over 18,000,000 people (ca. AD 2000) with a projected increase in population to nearly 25,000,000 by AD 2030 (CDWR 2005). As part of the South Coast hydrologic region, Southern California meets $23 \%$ of its combined agricultural and urban water demands directly from its own groundwater basins (Swartz and Hauge 2003). Therefore, future drying trends will produce a severe water demand and availability predicament (Seager et al. 2007). The region is characterized by an arid, Mediterranean climate (cool, wet winters and hot, dry summers) and faces a perennial freshwater availability crisis (Beuhler 2003). It is well known that the availability of freshwater to, and within, Southern California is controlled, fundamentally, by climate variability, which likely includes recent human-caused climate change (Barnett et al. 2008). Climate models suggest that future global warming will lead to increased aridity in Southern California (Seager et al. 2007). These model results present a serious challenge to water management and usage in Southern California. Critical to this challenge is the placement of modern and predicted climate change in the context of geologically recent climate change. Reconstructions of past climate provide a common method for assessing modern and future climate trends and predictions, particularly terrestrially-based reconstructions from the region (i.e. Southern California) of interest. The prehistoric record ( $>150$ years) of climate variability in Southern California is sparsely documented, and limited to Mission diaries, tree-ring studies, some palynology, and a few lake studies (see Kirby et al. 2007 for reference summary). Building on these previous studies, there is an on-going project that focuses specifically on the rare, but valuable lacustrine archives of Southern California (Kirby et al. 2004, 2005, 2006, 2007; Bird et al. 2010).

One of these archives is Lake Elsinore, southern California's largest natural lake (Fig. 1). Sediment cores from the lake's deepest basin are characterized by relatively high sedimentation rates $(\sim 1.0 \mathrm{~m} /$ 1,000 years over the Holocene) and nearly continuous sedimentation (Kirby et al. 2007). Holocene-scale trends (i.e. Milankovitch/orbital-scale) in environmental magnetic susceptibility, loss-on-ignition, \% $\mathrm{HCl}$-extractable $\mathrm{Al}$, and total inorganic $\mathrm{P}$ are interpreted to reflect long-term drying of the region in response to changes in winter-summer insolation and their respective effects on the seasonality of precipitation (Kirby et al. 2007).

To investigate the importance of higher frequency/ sub-orbital-scale climate change not addressed in Kirby et al. (2007), the authors measured 1-cm contiguous sediment grain size data from core LEGC03-3. The working hypothesis for this new data is straightforward: differences in grain size, particularly the very fine-to-fine sand, reflect changes in run-off dynamics as coupled to changes in atmospheric circulation (i.e. climate). Our hypothesis builds on the observations of: (1) Inman and Jenkins (1999) who show a strong positive relationship between sediment flux in the rivers of Southern California and intervals of increased precipitation during the twentieth century; and, (2) Cayan and Peterson (1989), Brito-Castillo et al. (2003), and Hanson et al. (2006), who show that higher streamflow/precipitation in southwestern North America is associated with a preferred mode of atmospheric circulation akin to the positive/warm phase of the PDO. Our paleo-run-off hypothesis is assessed through comparison to the twentieth century PDO index, Lake Elsinore lake level, San Jacinto River discharge, and sediment grain size over the past 100 years. Results indicate that sediment grain size, specifically percent very fine-to-fine sand, is a reasonable proxy for hydrologic change at a range of time scales. This modern relationship is used to develop a qualitative reconstruction of PDO-related, Holocene hydrologic variability. Results are 


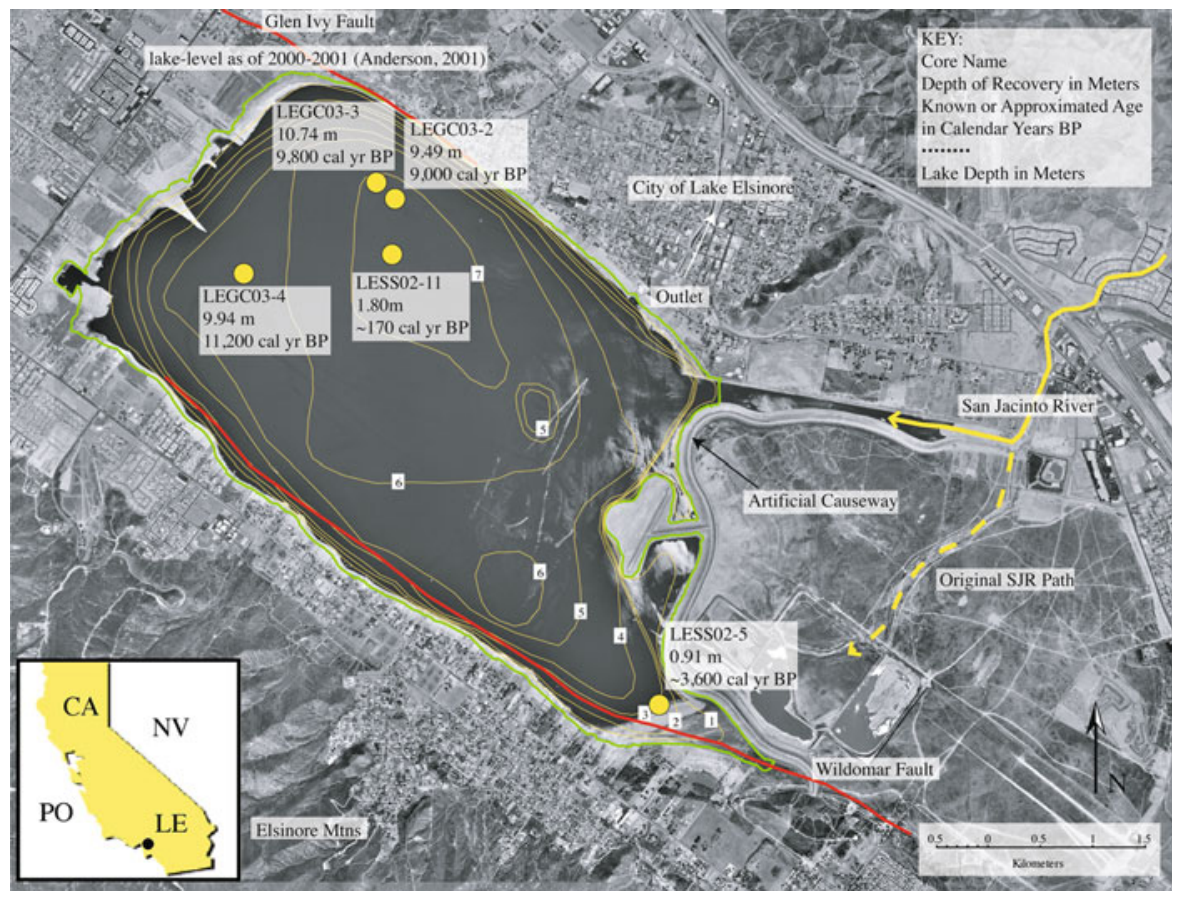

Fig. 1 Study site with regional inset map. $L E$ Lake Elsinore, $N V$ Nevada, $C A$ California, $P O$ Pacific Ocean. Core sites are shown with total core length $(\mathrm{m})$ and approximate basal age

compared to regional climate records and ENSO reconstructions. A depositional model is developed to explain the grain size proxy.

\section{Background}

\section{Regional climatology}

Present-day precipitation variability across southern California is a winter season occurrence. The amount of precipitation for the region is linked to the mean position of the winter season polar front, which is modulated by changes in the position of the eastern Pacific subtropical high (Cayan and Peterson 1989; Hanson et al. 2006). Under modern conditions, dry winters in Southern California are linked to a strong high-pressure ridge off the west coast of the United States. This configuration directs storms over the northwestern United States. Wet winters are related to a weakening of the subtropical high, causing a southward shift in the winter season storm track (Cayan and Peterson 1989). The large-scale atmospheric patterns that control storm trajectories are influenced by Pacific Ocean sea-surface conditions (Trenberth and Hurrell 1994). Interannual precipitation variability across Southern California is related to the El Niño-Southern Oscillation (ENSO hereafter; El Niño = higher precipitation in Southern $\mathrm{CA}$ and vice versa in northern $\mathrm{CA}$ ), whereas interdecadal variability is linked to the Pacific Decadal Oscillation (PDO hereafter; +PDO similar to El Niño effects) (Castello and Shelton 2004; Hanson et al. 2006; Wise 2010).

An examination of the relationship between twentieth century lake level at Lake Elsinore and regional precipitation indicates a strong positive correlation (Kirby et al. 2004, 2007). A similar comparison using the PDO also shows a positive relationship to lake level (Kirby et al. 2007). Together, these analyses indicate that large-scale ocean-atmosphere interactions are recorded at our study site and that Lake Elsinore responds to a broad range of spatial and temporal hydrologic change.

The contribution of summer-fall precipitation to Southern California is small under present conditions, though the effects can be severe, generating localized flooding, landslides, and lightning-formed forest fires (Tubbs 1972; Adams and Comrie 1997). Today, summer precipitation is a product generally of an expanded North American monsoon, which enhances 
local atmospheric convection and its associated thunderstorms, or waning tropical cyclones (Tubbs 1972). Between AD 1900 and AD 1997, there have been over 39 years with measurable precipitation attributed to waning tropical cyclones in Southern California (Williams 2005). From a paleoclimatological perspective, both Bird et al. (2010) and Kirby et al. $(2005,2007)$ argue that a wet early Holocene in southern California was, in part, caused by a regionally expanded and more intense North American Monsoon (NAM). Records from the Mojave Desert to the east of Lake Elsinore suggest a similar effect of the NAM on early Holocene climate (Enzel et al. 1992; Li et al. 2008). It is, however, very unlikely that summer precipitation outweighed winter precipitation in terms of total annual hydrologic budget at any time in the Holocene in southern California.

\section{Lake Elsinore}

Lake Elsinore is located along the northern Elsinore Fault zone, $120 \mathrm{~km}$ SE of Los Angeles, California (Fig. 1). Fault step-over from the Wildomar Fault to the Glen Ivy North Fault generates the Lake Elsinore pull-apart basin (Hull 1990). The Lake Elsinore Basin is $11 \mathrm{~km}$ long, $3.5 \mathrm{~km}$ wide, and less than 2 million years old (Hull 1990). As of March 2007, water occupies only $5.7 \mathrm{~km} \times 2.8 \mathrm{~km}$ of the total basin surface area, though the lake's surface area can change dramatically from year to year (Kirby et al. 2004, 2007). The lake is surrounded by a combination of predominantly igneous and metamorphic rocks (Hull 1990). It is constrained along its southern edge by the steep, deeply incised Elsinore Mountains that rise to more than $900 \mathrm{~m}$ above lake level. The Elsinore Mountains likely provide a local sediment source during heavy precipitation years and/or wet climates (Kirby et al. 2004, 2007). The lake's drainage basin is relatively small $\left(<1,240 \mathrm{~km}^{2}\right)$ from which the San Jacinto River flows (semi-annually) into and terminates within the lake's basin (Fig. 1) (Kirby et al. 2004). Lake Elsinore has overflowed to the northwest through Walker Canyon very rarely, only three times in the twentieth century and 20 times since AD 1769, according to mission diaries (Kirby et al. 2004, 2007). Each overflow event lasted for a short period of time, demonstrating that Lake Elsinore is essentially a closed-basin lake system, at least over the past few hundred years (Kirby et al. 2004,
2007). Conversely, Lake Elsinore has dried completely on only four occasions since AD 1769 (Kirby et al. 2004, 2007). Unexpectedly, only sediments younger than 450 calendar years before present (hereafter cal year BP) in core LEGC03-3 contain mudcracks. Because core LEGC03-3 is from the lake's deepest basin, the lack of mudcracks older than 450 cal year BP suggests that whole lake desiccation is a relatively recent phenomenon in Lake Elsinore's Holocene history. In addition, this finding argues that sedimentation at core site LEGC03-3 was probably uninterrupted over the age interval addressed in this paper. Recently acquired seismic reflection data from Lake Elsinore support the latter statements (Pyke et al., pers. commun.).

Lake Elsinore is a shallow, polymictic lake (13 m maximum depth based on historic records) (Anderson 2001a). The hypolimnion is subject to short periods (i.e. days to weeks) of anoxia (Anderson 2001a); however, frequent mixing of oxygen-rich epilimnetic waters into the hypolimnion precludes permanent, sustained anoxia, at least during the period of observation. Over a 24-month period between April 2007 and 2009, surface salinity ranged from a high of $2,850 \mathrm{EC}(\mu \mathrm{S} / \mathrm{cm})$ to a low of $2,170 \mathrm{EC}(\mu \mathrm{s} / \mathrm{cm})$ (J. Noblet, pers. commun.). Highest surface salinities occur generally in late fall-early winter before the onset of winter rain. Evaporation accounts for $>1.4 \mathrm{~m} /$ year water loss. Consequently, water residence time in Lake Elsinore is short at all times and shorter during drought periods (Anderson 2001a).

\section{Methods}

Core acquisition

Two sediment cores (LEGC03-2 [949 cm], LEGC03$3[1,074 \mathrm{~cm}])$ were extracted using a hollow-stemmed auger drill corer aboard a floating and stabilized drilling platform (Fig. 1; Table 1). Cores LEGC03-2 and LEGC03-3 were taken from within $200 \mathrm{~m}$ horizontal distance from one another in the lake's present day deepest basin (Fig. 1). Kirby et al. (2007) demonstrated that cores LEGC03-2 and LEGC03-3 (hereafter core 3) are correlated at centimenter-scale resolution; therefore, only core 3 , the most complete core, was used for grain size analysis and is discussed in this paper. In several cores, sediment was missing or 
Table 1 Core information (Water Depth as of November 2003)

\begin{tabular}{llllr}
\hline Core ID & Water depth $(\mathrm{cm})$ & Latitude & Longitude & Core length $(\mathrm{cm})$ \\
\hline LEGC03-2 & $16^{\prime} 6^{\prime \prime}(5.0 \mathrm{~m})$ & $\mathrm{N} 33^{\circ} 40.330$ & $\mathrm{~W} 117^{\circ} 21.186$ & 949 \\
LEGC03-3 & $16^{\prime}(4.9 \mathrm{~m})$ & $\mathrm{N} 33^{\circ} 40.395$ & $\mathrm{~W} 117^{\circ} 21.250$ & 1,074 \\
LEGC03-4 & $13^{\prime}(4.0 \mathrm{~m})$ & $\mathrm{N} 33^{\circ} 40.044$ & $\mathrm{~W} 117^{\circ} 21.848$ & 994 \\
\hline
\end{tabular}

disturbed at the top of the core sections. This observation is consistent with minor over-augering between drives or sediment disturbance of the core top during the coring process. In all cases, it is assumed that the core bottoms represent the intended depth of coring. Recovery for core 3 was $85 \%$. For the purposes of age control, core LESS02-11 (hereafter core 11, Kirby et al. 2004) is also discussed in this paper. Core 11 was extracted south of core 3 in the same deep basin.

\section{Age control}

In the absence of salvageable macro- or microorganic matter, bulk organic matter was used for age control (Table 2). Eight dates were measured on core LEGC03-2 and 18 dates were measured on core 3. All dates were measured at the University of California, Irvine Keck AMS Facility, and samples were pre-treated with an acid wash to remove carbonate. Age control for sediments less than 150 cal years BP was transferred from core 11 to core 3 (details in Sect. "Results").

Core sedimentology and grain size

Core 3 sedimentology is based on a combination of visual description, grain size analysis, environmental magnetic susceptibility, LOI $550^{\circ} \mathrm{C}$, and LOI $950^{\circ} \mathrm{C}$ (see Kirby et al. 2007 for latter three analytical methods). Core 3 grain size was determined on approximately $0.1-0.5 \mathrm{~cm}^{3}$ of sediment at $1-\mathrm{cm}$ contiguous intervals. Samples were boiled in DI water and pre-treated with at least $30 \mathrm{ml}$ of $30 \% \mathrm{H}_{2} \mathrm{O}_{2}$ to remove organics. Biogenic silica (i.e. diatoms) is almost entirely absent in the lake sediments (A. Bloom, pers. commun. 2007); therefore, we did not process the sediments to remove biogenic silica. The sediments were not pre-treated with $\mathrm{HCl}$ because carbonate microfossils (e.g. ostracods [gastropods are completely absent]) are extremely rare and poorly preserved in the Holocene section. Furthermore, we opted to include the micron-size, chemically precipitated $\mathrm{CaCO}_{3}$ (Anderson 2001a, b) as a part of the lake's total inorganic, minerogenic size fraction and therefore did not acidify the sediments. Prior to grain size analysis, but after organic removal, samples were split using a TFE fluoro-carbon plastic riffle splitter with $2,000-\mu$ slots. Samples were split, if necessary, to achieve an obscuration of $8-14 \%$ (Malvern Instruments 1999).

All samples were run on a Malvern Mastersizer 2000 laser diffraction grain size analyzer coupled to a Hydro 2000G. At the beginning of each measurement day, a tuff standard (TS2) with a known distribution between 1.0 and $16.0 \mu$ (avg. $4.54 \mu \pm 0.07 ; n=$ 3,194 ) was measured twice and compared to past measurements to assess the equipment's accuracy and repeatability. Thereafter, TS2 was run every 10 samples to verify analytical repeatability and stability and once at the end of the day's analyses for a final assessment. TS2 results are compared to values obtained by measuring known Malvern standards as an additional measure of stability. The measurement principle used is the Mie Scattering principle. Sample measurement time was $30 \mathrm{~s}$ with 30,000 measurement snaps per single sample aliquot averaged per 10,000 snaps. The final three measurements $(30,000$ measurements/10,000 snaps $=3$ time-averaged measurements) were compared for internal consistency per sample. All data are reported as volume percent and divided into 10 grain-size intervals as well as $d(0.1)$, $d(0.5), d(0.9)$, \%clay, \%silt, \%sand, and mode.

The total percent sand data were standardized by subtracting the mean of the distribution (as calculated between 150 and 9,700 cal year BP) from each observation, and dividing the value by the standard deviation (as calculated between 150 and 9,700 cal year BP). The standardization process creates a mean of zero with deviations from the mean in units of standard deviation. The standardized data were also binned into 50-year intervals to assess multi-decadalto centennial-scale variability. The anthropogenic interval ( -53 to $150 \mathrm{cal}$ year $\mathrm{BP}$ or $\mathrm{AD} 2003$ to $\mathrm{AD}$ 1800 [0 cal years $\mathrm{BP}=\mathrm{AD} 1950]$ ) was not included in the standardization calculation because of the 
Table 2 Pollen age and radiocarbon analyses

\begin{tabular}{|c|c|c|c|c|c|c|c|c|c|}
\hline Number & Core ID & $\begin{array}{l}\text { Depth } \\
\text { interval }\end{array}$ & $\begin{array}{l}\text { Core } 3 \\
\text { equivalent }\end{array}$ & UCIAMS ID & $\delta^{13} \mathrm{C}(\% 0)$ & ${ }^{14} \mathrm{C}$ Age (BP) & \pm & $\begin{array}{l}\text { Calendar } \\
\text { years BP }\end{array}$ & $\begin{array}{l}\text { 2-Sigma } \\
\text { range }\end{array}$ \\
\hline $\begin{array}{l}0 \text { (pollen: Kirby } \\
\text { et al. 2004) }\end{array}$ & LESS02-11 & 150 & 150 & & & & & 150 & Pollen \\
\hline 1 & LEGC03-2 & 298-299 & 299.5 & 8,260 & -17.8 & 2,290 & 20 & 2,330 & $2,307-2,348$ \\
\hline 2 & LEGC03-2 & $405-406$ & 396.5 & 6,832 & -21.0 & 2,075 & 25 & 2,060 & $1,987-2,123$ \\
\hline 3 & LEGC03-2 & $405-406$ & 396.5 & 6,695 & -14.2 & 2,060 & 35 & 2,030 & $1,932-2,122$ \\
\hline 4 & LEGC03-2 & $432-433$ & 421.93 & 8,261 & -16.2 & 2,915 & 25 & 3,020 & $2,957-3,081$ \\
\hline 5 & LEGC03-2 & $556-557$ & 533.79 & 8,262 & -15.2 & 4,385 & 30 & 4,930 & $4,864-4,996$ \\
\hline 6 & LEGC03-2 & $624-625$ & 614.17 & 6,833 & -15.8 & 4,605 & 25 & 5,420 & $5,396-5,449$ \\
\hline 7 & LEGC03-2 & $850-851$ & 818.69 & 6,834 & -14.4 & 6,825 & 30 & 7,650 & $7,606-7,697$ \\
\hline 8 & LEGC03-2 & $947-948$ & 899 & 6,835 & -17.7 & 7,350 & 30 & 8,160 & $8,106-8,196$ \\
\hline $9^{\mathrm{a}}$ (reworked) & LEGC03-3 & $105-106$ & 105.5 & 8,263 & -20.7 & 860 & 25 & 740 & $694-794$ \\
\hline 10 & LEGC03-3 & $162-163$ & 162.5 & 8,264 & -20.4 & 650 & 20 & 580 & $559-602$ \\
\hline 11 & LEGC03-3 & $195-196$ & 195.5 & 8,265 & -17.9 & 1,180 & 20 & 1,110 & $1,055-1,171$ \\
\hline 12 & LEGC03-3 & $264-265$ & 264.5 & 8,266 & -17.5 & 1,115 & 25 & 1,010 & $962-1,062$ \\
\hline 13 & LEGC03-3 & $324-325$ & 324.5 & 8,267 & -18.4 & 2,270 & 30 & 2,220 & $2,179-2,265$ \\
\hline 14 & LEGC03-3 & 395-396 & 395.5 & 8,268 & -20.3 & 2,610 & 20 & 2,750 & $2,734-2,774$ \\
\hline 15 & LEGC03-3 & $469-470$ & 469.5 & 8,270 & -17.6 & 3,160 & 25 & 3,400 & $3,341-3,453$ \\
\hline 16 & LEGC03-3 & $536-537$ & 536.5 & 8,271 & -19.2 & 3,125 & 20 & 3,350 & $3,321-3,385$ \\
\hline 17 & LEGC03-3 & $610-611$ & 610.5 & 8,272 & -16.1 & 5,160 & 30 & 5,920 & $5,888-5,950$ \\
\hline $18^{\mathrm{a}}$ (event layer?) & LEGC03-3 & $635-636$ & 635.5 & 8,274 & -18.4 & 4,955 & 30 & 5,670 & $5,609-5,735$ \\
\hline $19^{\mathrm{a}}$ (event layer?) & LEGC03-3 & $683-684$ & 683.5 & 8,275 & -18.1 & 4,945 & 30 & 5,670 & $5,606-5,728$ \\
\hline 20 & LEGC03-3 & $713-714$ & 713.5 & 8,277 & -17.6 & 6,025 & 35 & 6,850 & $6,745-6,949$ \\
\hline 21 & LEGC03-3 & $759-760$ & 759.5 & 8,278 & -17.3 & 5,820 & 30 & 6,610 & $6,532-6,679$ \\
\hline 22 & LEGC03-3 & $800-801$ & 800.5 & 8,279 & -18.1 & 5,540 & 40 & 6,340 & $6,279-6,407$ \\
\hline 23 & LEGC03-3 & $924-925$ & 924.5 & 8,280 & -19.4 & 7,910 & 50 & 8,700 & $8,595-8,813$ \\
\hline 24 & LEGC03-3 & $986-987$ & 986.5 & 8,283 & -14.9 & 8,465 & 40 & 9,500 & $9,464-9,532$ \\
\hline 25 & LEGC03-3 & $1,048-1,049$ & $1,048.5$ & 8,284 & -17.0 & 8,225 & 40 & 9,180 & $9,057-9,301$ \\
\hline 26 & LEGC03-3 & $1,071-1,072$ & $1,071.5$ & 8,286 & -18.0 & 7,965 & 40 & 8,850 & $8,695-8,999$ \\
\hline
\end{tabular}

Calib 4.4.2, Stuiver and Reimer (1993)

a Not used in age model

much higher-than-Holocene average, post-settlement sand values. From AD 1900 to AD 2003, the sand data were standardized using the $\mathrm{AD} 1900$ to $\mathrm{AD}$ 2003 average and standard deviation. These modern data were binned into 10-year averages (e.g. AD 1910-1919, AD 1920-1929, etc.) for comparison to lake level, river discharge, and PDO data.

Meteorological indices and lake level data

Meteorological data were obtained from the National Climatic Data Center weather observation station records (lwf.ncdc.noaa.gov/oa/climate/stationlocator. html). Lake level data for Lake Elsinore were obtained from the United States Geological Survey, the Elsinore Valley Municipal Water District monitoring program (www.evmwd.com), and Berry et al. (1953). San Jacinto River discharge data were obtained from the USGS Water Data for the Nation website (nwis. waterdata.usgs.gov/nwis). PDO data were obtained from Mantua et al. (1997; [http://jisao.washington.edu/ pdo/PDO.latest]). The PDO, lake level, and discharge data were binned into 10-year averages (e.g. AD 1910-1919, AD 1920-1929, etc.) so that their time intervals correspond to that of the typical sand datum. Intervals of missing lake level data were substituted 
with values interpolated between points of known data using a linear interpolation (i.e. AD 1998-1999, 1991, 1989-1984, 1972-1971, 1968, 1966, 1963-1960) based on the relationship between precipitation and the predictable lake level response in an arid environment. Binning the sand, PDO, discharge, and lake level data by mid-decade (i.e. AD 1905-1914) does not change the relationships between the various data.

\section{Results}

Age control

Following Kirby et al. (2007), ages from core LEGC03-2 were transferred to core 3 using centimenter-scale sedimentological data to create a single age model for core 3 spanning $150 \mathrm{cal}$ year BP to $\sim 9,700$ cal year BP (Fig. 2a; Table 2). Three dates were not used in the age model due to suspected reworking (Table 2). The date at $105-106 \mathrm{~cm}$ is stratigraphically above the Eucalyptus pollen age (AD 1910) at $110 \mathrm{~cm}$, and it is therefore considered too old. Both dates at 635 and $683 \mathrm{~cm}$ are from thin, sharply bounded units with higher-than-average magnetic susceptibility and $\mathrm{C}: \mathrm{N}$ ratios (data not shown), which indicate potential reworking of terrestrial organic matter, thus confounding the bulk organic carbon ages. An age model for the last 150 calendar years was developed by cross-correlating ages from core 11 (Kirby et al. 2004) to core 3 (Fig. 2b, c). An exotic pollen age (Erodium cicutarium: $\mathrm{AD} 1,800 \pm 20$ years, or 150 cal year $\mathrm{BP} \pm$ 20 years) from core 11 was transferred to core 3 through comparison of similar percent total carbonate profiles (Table 3; Fig. 2b, c). The transferred Erodium date was used to "pin" the upper age for the core 3 age model at 150 cal year BP (Mensing and Byrne 1998). Because the best-fit line for core 3 overestimates the pinned 150 cal year BP age transferred to core 3 by 130 years (i.e. 280 cal year BP), this amount was subtracted from the best-fit line equation
Fig. 2 a Age model for core LEGC03-3. b Inset core model for the past 150 cal year BP based on age data from core LESSO211 (Kirby et al. 2004). c Correlation between core LESS02-11 and LEGC03-3 using percent total inorganic carbon and LOI $950^{\circ} \mathrm{C}$ data

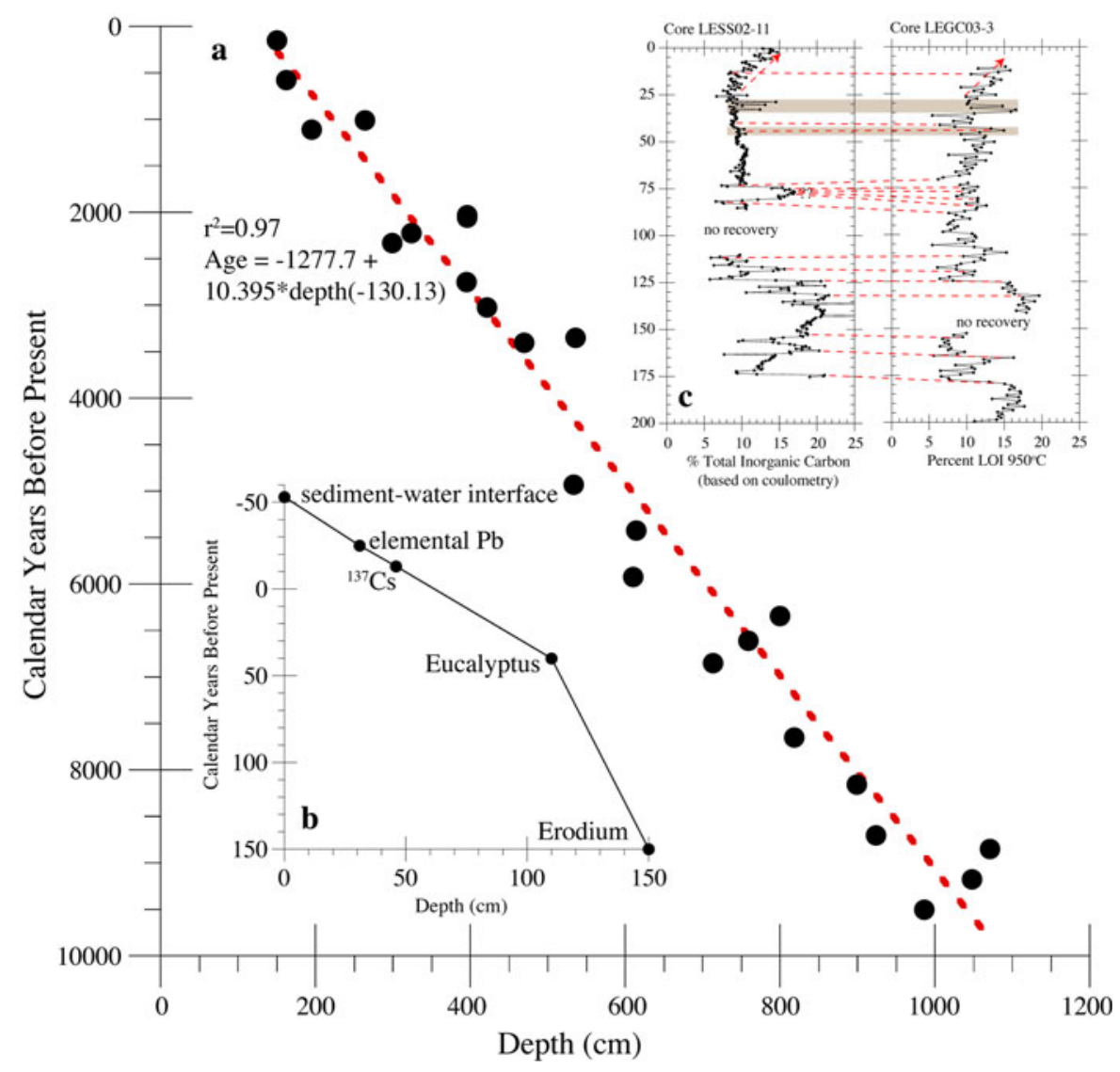


Table 3 Core LESS02$11 \mathrm{ab}$ and Core LEGC03-3 age-depth correlations

\begin{tabular}{|c|c|c|c|c|c|c|}
\hline $\begin{array}{l}\text { Table } 3 \text { Core LESSO2- } \\
11 \mathrm{ab} \text { and Core LEGC03-3 } \\
\text { age-depth correlations }\end{array}$ & $\begin{array}{l}\text { Depth }(\mathrm{cm}) \text { Core } \\
\text { LESS02-11 ab }\end{array}$ & $\begin{array}{l}\text { Depth }(\mathrm{cm}) \text { Core } \\
\text { LEGC03-3 }\end{array}$ & $\mathrm{AD}$ age & $\begin{array}{l}\text { Age } \\
\text { range }\end{array}$ & cal year BP & Material \\
\hline & 0 & 0 & 2003 & 0 & -53 & Intact surface \\
\hline & 31 & 31 & 1975 & 5 & -25 & Elemental $\mathrm{Pb}$ \\
\hline & 46 & 46 & 1963 & 0 & -13 & ${ }^{137} \mathrm{Cs}$ \\
\hline & 110 & 110 & 1910 & 10 & 40 & Exotic pollen (Eucalyptus) \\
\hline & 150 & 150 & 1800 & 20 & 150 & Exotic pollen (Erodium) \\
\hline
\end{tabular}

${ }^{\text {a }}$ Kirby et al. (2004)

for core 3 to account for this small over-estimation. In addition to the Erodium age, three other dates (elemental $\mathrm{Pb},{ }^{137} \mathrm{Cs}$, and Eucalyptus appearance) were transferred from core 11 to core 3 to fine-tune an age model for the past 150 calendar years (Table 3; Fig. 2b). Additional details for the dates from core 11 are provided in Kirby et al. (2004). Independent age support for the Holocene LEGC03-3 age model is detailed in the Sect. "Discussion". Of note, the Kirby et al. (2007) age model has been slightly altered by the addition of grain size and geochemical data, which results in a more conservative measure for discarding dates. Therefore, the age model for this paper discards 3 dates [4 in Kirby et al. (2007)] and results in a $\sim 73$-year difference in age per depth between the two papers. Because the Kirby et al. (2007) paper considered only Holocene-scale (i.e. Milankovitch scale) variability, the new age model presented in this paper does not change the Kirby et al. (2007) paper's interpretations.

Core sedimentology and grain size

Results for environmental magnetic susceptibility, LOI $550^{\circ} \mathrm{C}$, and LOI $950^{\circ} \mathrm{C}$ in core 3 are detailed in Kirby et al. (2007). Magnetic susceptibility is weakly correlated to clay ( $n=864, r=0.35, p<0.0001)$, silt $(n=864, r=-0.29, p<0.0001)$, and sand ( $n=864, r=-0.17, p<0.0001$ ) indicating that the magnetic signal is likely related to changes in organic matter content as proposed by Kirby et al. (2007). Core 3 is dominantly grey, homogenous clayey silt with occasional very-fine-to-fine sand intervals (most intervals are $<1-2-\mathrm{cm}$ thick), fine enough that they are rarely distinguishable to the naked eye (Figs. 3, 4). The core contains infrequent, but occasionally visible $\mathrm{CaCO}_{3}$ "specks" ( $<5-\mathrm{mm}$ diameter when visible) at $712 \mathrm{~cm}$ and between 758 and $861 \mathrm{~cm}$. Sand is very weakly correlated to LOI $950^{\circ} \mathrm{C}(n=863, r=0.20$, $p<0.0001$ ) indicating that less than $4 \%$ of the sand signal is related to changes in carbonate content. In other words, these infrequent $\mathrm{CaCO}_{3}$ "specks" are not inflating the sand data. A distinct color change occurs between $715 \mathrm{~cm}$ and $610 \mathrm{~cm}$, respectively, in both cores 2 and 3. Rounded mud clasts occur at $670 \mathrm{~cm}$ in both cores as well, perhaps associated with a large storm event; however, this interpretation is equivocal because the features are near the top of a core section and therefore could represent an artifact of the coring process. Core 3 is also characterized by occasional sediment units with secondary features such as mud cracks and distinct bioturbation in the upper $250 \mathrm{~cm}$ only.

Percent sand (62.50-2,000.00 $\mu$ ), silt (3.90-62.49 $\mu$ ), and clay $(<3.89 \mu)$ are shown in Fig. 4 . The core sediment is predominantly silt, with a $150-9,700 \mathrm{cal}$ year BP average value of $65.23 \%$. For the same interval, clay averages $31.31 \%$ and sand $3.32 \%$. Present day to $150 \mathrm{cal}$ year BP average values for sand $(8.05 \%)$ and clay $(24.17 \%)$ are considerably different from the $150-9,700$ cal year BP averages due to human development in the drainage basin. For the whole time period (present day to 9,700 cal year BP), clay and silt are strongly negatively correlated ( $n=868, r=-0.85, p<0.0001$ ); clay and sand are moderately negatively correlated $(n=868, r=-0.46$, $p<0.0001)$; and, silt and sand are not correlated $(n=868, r=-0.07, p<0.05)$. Very fine sand $(62.50-124.99 \mu)$ is also the dominant sand size fraction, accounting for more than $84 \%$ on average of the total sand fraction $(62.50-2,000.00 \mu)$ for the interval $150-9,700 \mathrm{cal}$ year BP; for the interval -53 to $150 \mathrm{cal}$ year BP, the average very fine sand out of the total sand fraction decreases slightly, at the expense of larger sand sizes, to $77 \%$ (Fig. 5). This clarification is important because the vast majority of 
Fig. 3 Stratigraphic column for core LEGC03-3 with percent silt and sand

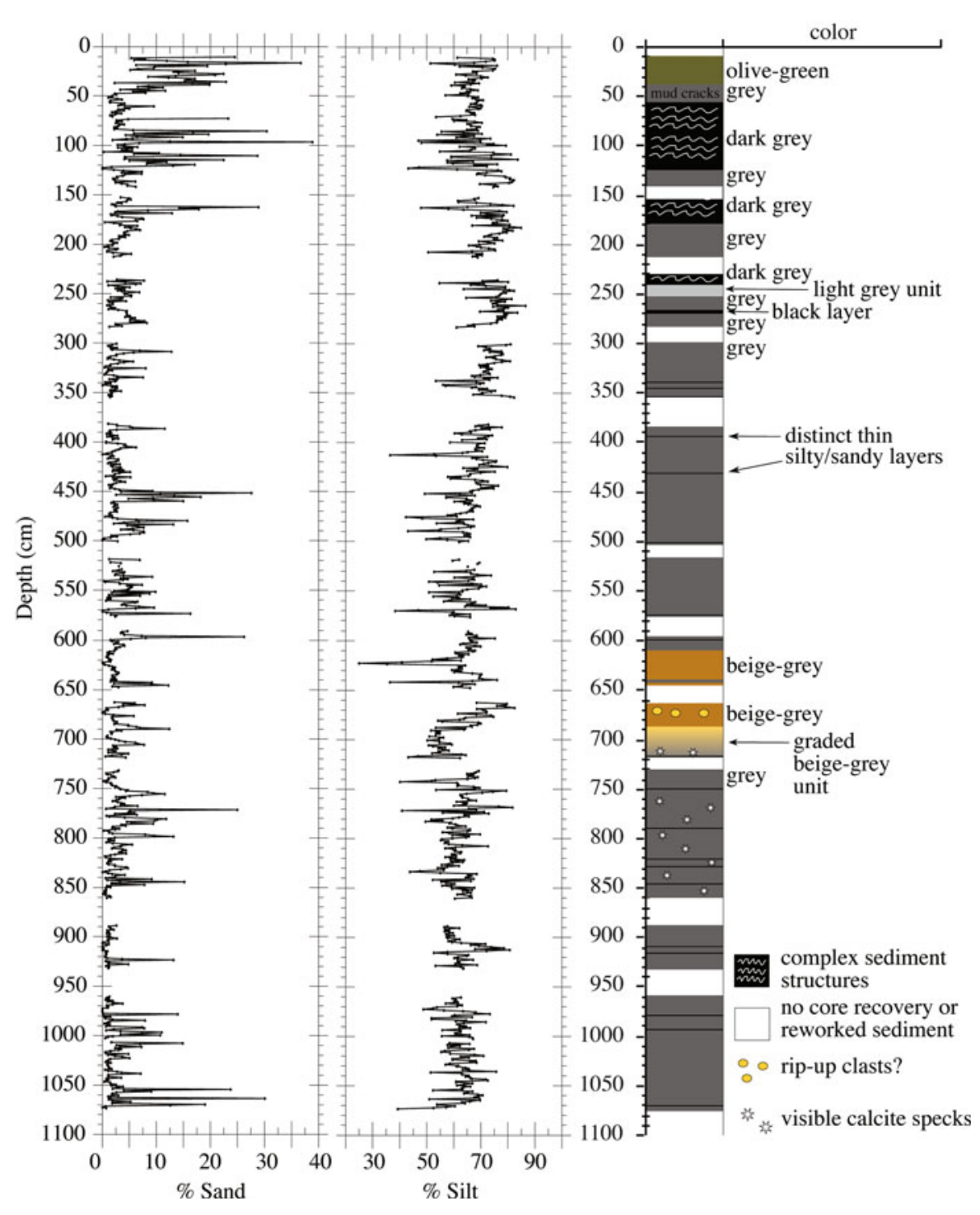

changes in sand content are within the very fine sand size range, they are gradual and they are not discernible (without quantitative grain size analysis) at a facies scale; therefore, very few, if any, increases in sand are interpreted to represent unequivocal evidence for individual storm deposits (Figs. 3, 5). Figure 6 shows the percent total sand plotted $>1.5$ standard deviations above the 150-9,700 cal year BP percent total sand average. Not including the interval -53 to 150 cal year BP, there are six sand values $>1.5$ standard deviation between 150 and 3,200 cal year BP and 41 such values between 3,200 and 9,700 cal year BP. The raw, standardized, and 50-year binned percent total sand data are shown in Fig. 7.

\section{Discussion}

Development and assessment of a grain size PDO-related hydrological proxy

Inman and Jenkins (1999) examined the relationship between twentieth century climate along the central and southern Californian coasts and sediment flux in the region's rivers. Their study revealed the strong positive coupling between periods of wet climate and enhanced river sediment flux. Conversely, dry climates reduce the flux of sediment in the region's rivers. Cayan and Peterson (1989), Brito-Castillo et al. (2003), and Hanson et al. (2006) examined the 

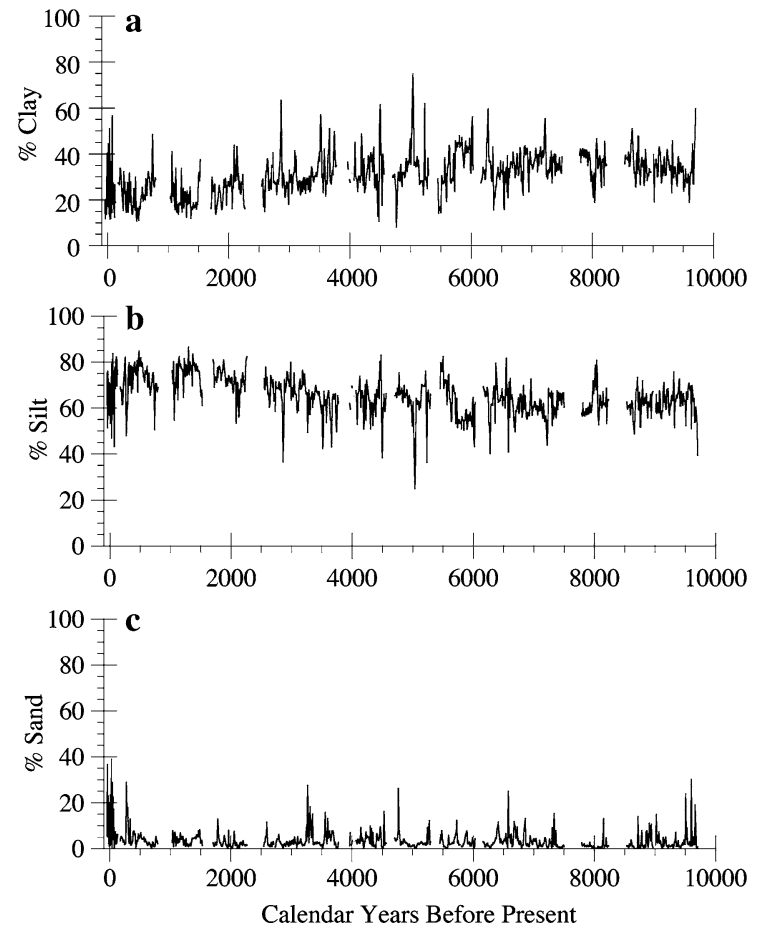

Fig. 4 a Percent clay versus age. b Percent silt versus age. c Percent sand versus age

relationship between patterns of atmospheric circulation and streamflow/precipitation in western North America. Their combined results indicate that higher streamflow is associated with preferred modes of atmospheric circulation. For the southwestern United States, this preferred mode is similar to the positive, or warm phase of the Pacific Decadal Oscillation (Cayan and Peterson 1989; Brito-Castillo et al. 2003; Hanson et al. 2006). Together, these results indicate that (1) wet/high streamflow years in Southern California are associated with a preferred (predictable?) mode of atmospheric circulation akin to the positive/warm phase of the PDO, and (2) wet/high streamflow years in Southern California result in higher river competence/capacity. Using these two results, we developed a general working hypothesis for our paper, which states that differences in grain size reflect changes in run-off dynamics as coupled to changes in atmospheric circulation (i.e. climate).

Kirby et al. $(2004,2007)$ have shown that Lake Elsinore lake level, despite recent human development in the drainage basin, reflects both local and regional precipitation variability. As expected, however, lake level mutes higher frequency precipitation
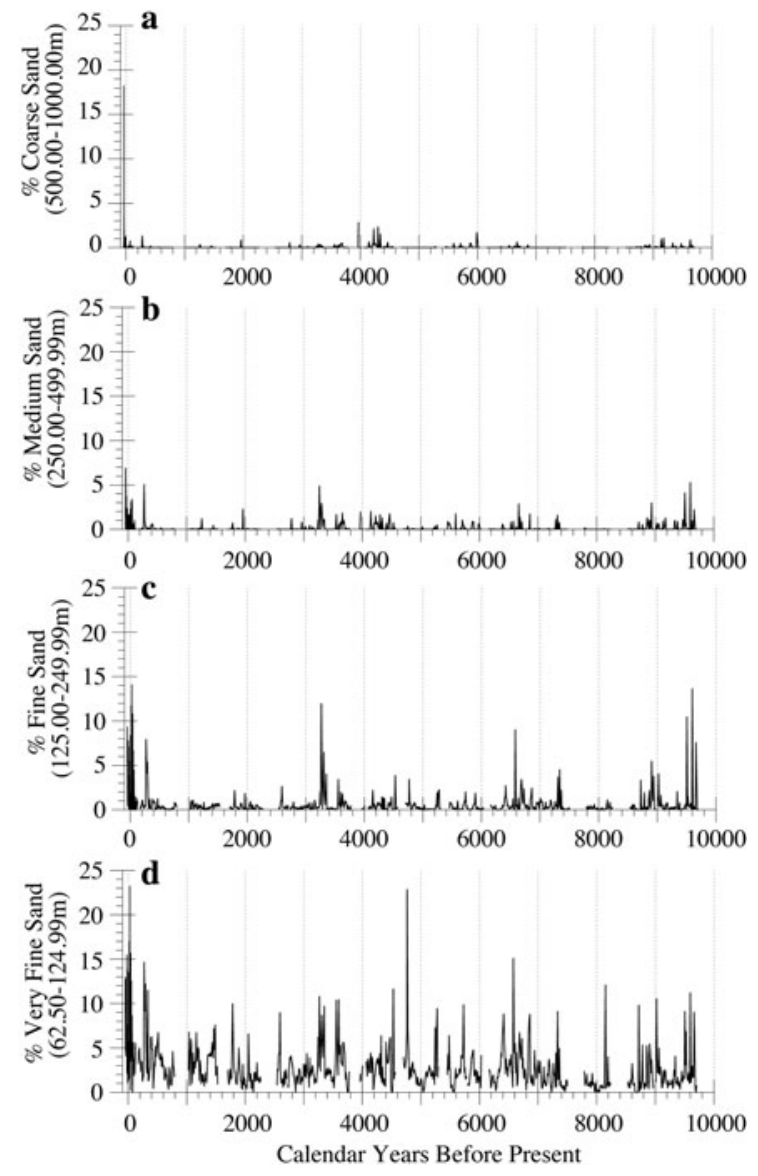

Fig. 5 Individual percent sand classes from coarse sand (a) to very fine sand (d)

variability and reflects better the decadal-to-multidecadal average precipitation. To assess this decadalto-multi-decadal climate influence, Kirby et al. (2007) compared Lake Elsinore lake level to the Pacific Decadal Oscillation and noted a strong positive correlation. San Jacinto River discharge also reflects the combination of annual through decadal precipitation variability. In all, it is clear that Lake Elsinore, as a hydrologic entity, responds directly to climate change (Fig. 8).

Inman and Jenkins (1999) have already shown that river sediment flux and regional climate are positively correlated in Southern California. Building on this relationship, we hypothesize that differences in grain size reflect changes in run-off dynamics as coupled to changes in atmospheric circulation. In other words, wetter climates increase run-off, increase river competence/capacity, and increase the 
Fig. 6 Percent total sand versus age. Dashed line indicates cut-off percent (8.8\%) for sand values greater than 1.5 standard deviations above the $150-9,700$ cal year BP average

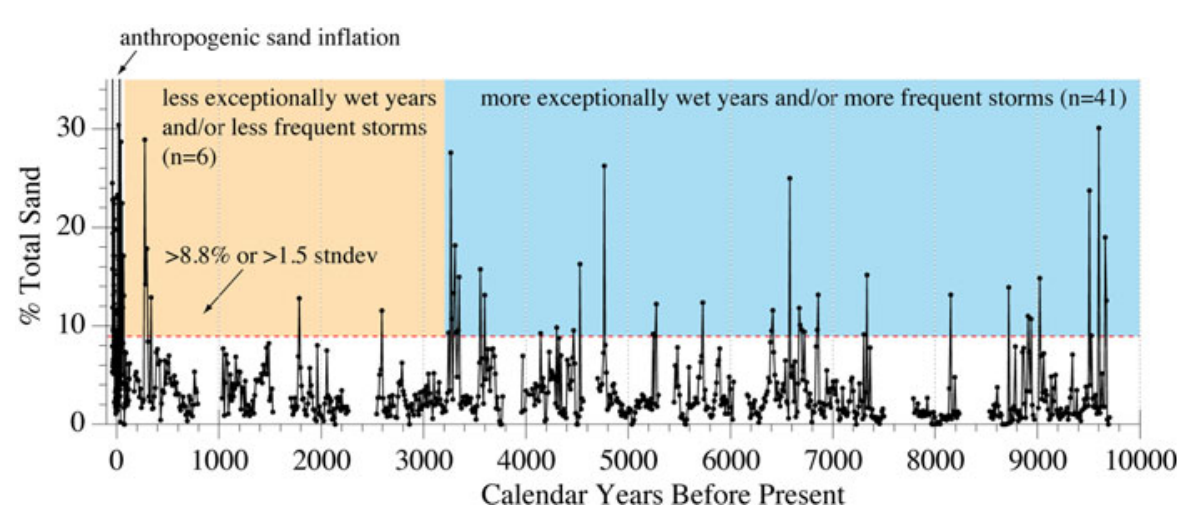

Fig. 7 a Percent total sand. b Standardized percent total sand. c 50-year binned standardized percent total sand. Grey box highlights the recent human disturbance interval

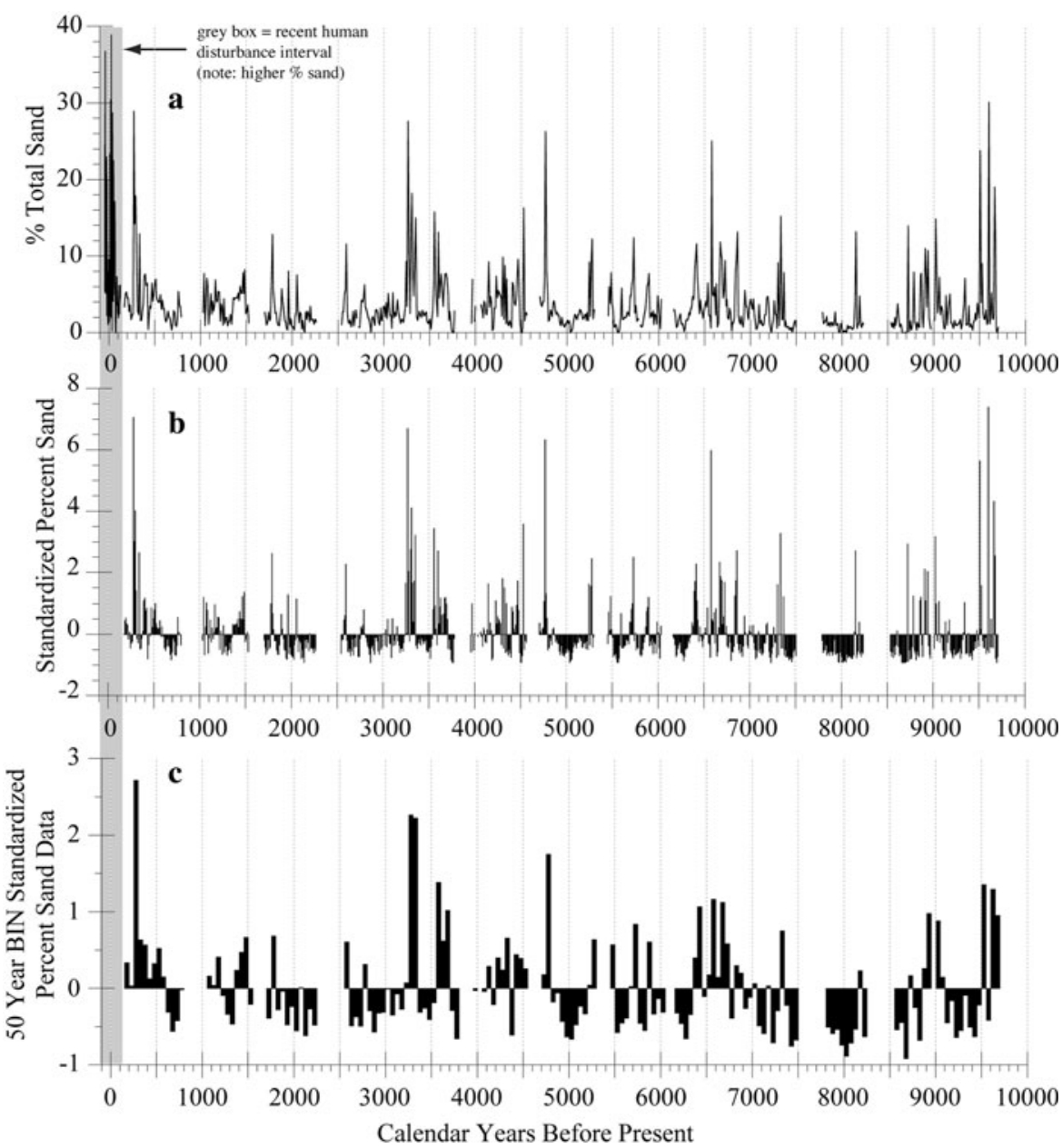

average grain size transported to, and deposited in, Lake Elsinore. The idea of using grain size as a proxy for climate is well-documented. Recently, Parris et al. (2010) reconstructed a history of storm activity in the NE USA using changes in grain size. Conroy et al. (2008) used grain size to infer changes in lake level and El Niño-Southern Oscillation variability in a small lake in the Galapagos Islands. Anderson (1977, 2001b) demonstrated that enhanced river discharge and changes from dry to wet climates increase the sand content in arid-environment lakes. Anderson also illustrated the importance of mechanisms, such 
as density overflow during high river discharge, for transporting coarse-grain sediment far into the lake basin. Benson et al. (1991) used grain size to infer changes in the size of Walker Lake, though their grain size data conflicted with other proxy data at times. Of note, Yair and Kossovsky (2002) and Dearing (1991) caution against simple climate-sediment flux models, suggesting that surface properties and disturbance (e.g. human history, fires, changes in surface properties) may act as the primary controls on changes in the flux of sediment from a lake's drainage basin. For arid environments, however, sediment flux may be tied more simply to climate change than for other environments (Hunt and $\mathrm{Wu}$ 2004; Collins and Bras 2008).

Comparisons between twentieth century total sand and Lake Elsinore lake level, San Jacinto River discharge, regional precipitation, and the PDO reveal intriguing relationships: higher total sand generally corresponds to higher lake level, increased river discharge, more precipitation, and a positive PDO index (Fig. 8). The pre- 150 cal year BP record is sampled at $1-\mathrm{cm}$ contiguous intervals, which equates to about eight years per sample. Therefore, a better comparison than the annual data shown by Fig. 8 is to bin the twentieth century data into 10 -year averages and re-assess the relationships. The process of binning the twentieth century data provides insights into the time-averaging effect associated with the pre150 cal year BP, $\sim 8$ year/sample effect generated by $1-\mathrm{cm}$ contiguous sampling. The results are shown in Fig. 9 and indicate that total sand, predominantly very fine sand (see Sect. "Results" and Fig. 5) is a reasonable proxy for the PDO, San Jacinto River discharge, and lake level. Because the binning process time-averages the data, we do not attempt to create a statistical transfer function from these comparisons. Therefore, we consider this proxy qualitative. Nonetheless, this comparison suggests that our working hypothesis is reasonable and that total sand records a combination of local (i.e. lake level/discharge) and regional (i.e. PDO-related) climate variability.

As an independent assessment of the Lake Elsinore sand-PDO proxy, we compared the percent total sand versus the MacDonald and Case (2005) tree-ring PDO reconstruction (Fig. 10). We used the MacDonald and Case (2005) reconstruction because it was constructed, in part, from trees located in Southern California. Like the twentieth century comparison, we binned the

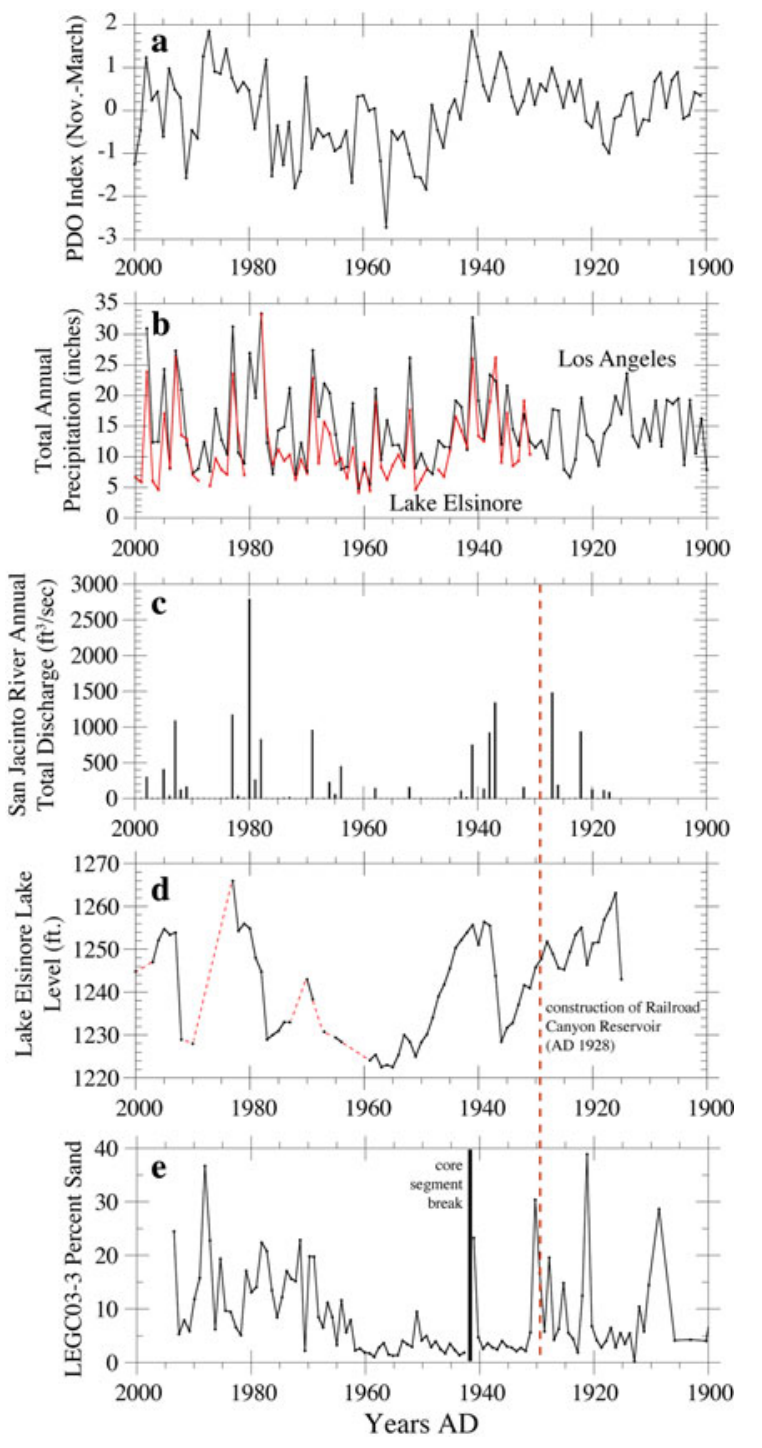

Fig. 8 Twentieth century lake, river, PDO, and core data. a November to March Pacific Decadal Oscillation Index data (http://jisao.washington.edu/pdo/PDO.latest). b Total annual precipitation for Los Angeles (black) and Lake Elsinore (red). c San Jacinto River annual total discharge $\left(\mathrm{ft}^{3} / \mathrm{sec}\right)$. d Lake Elsinore lake level (ft). Dashed lines represent intervals of no measured data. e LEGC03-3 percent total sand data. Black solid line represents the location of the core segment break. Dashed vertical line spanning $\mathbf{c}, \mathbf{d}$, and e represents the date (AD 1928) Railroad Canyon Reservoir Dam was built. The dam is approximately $5 \mathrm{~km}$ up the San Jacinto River from its inlet location at the west end of Lake Elsinore. Note that the dam's construction has little, if any, lasting effect on lake sedimentation younger than AD 1928, as shown by $\mathbf{c}, \mathbf{d}$, and $\mathbf{e}$

MacDonald and Case (2005) annual PDO index values into 10-year average bins from AD 1800 to AD 1100 for a better comparison to the 8 year/sample integrated 

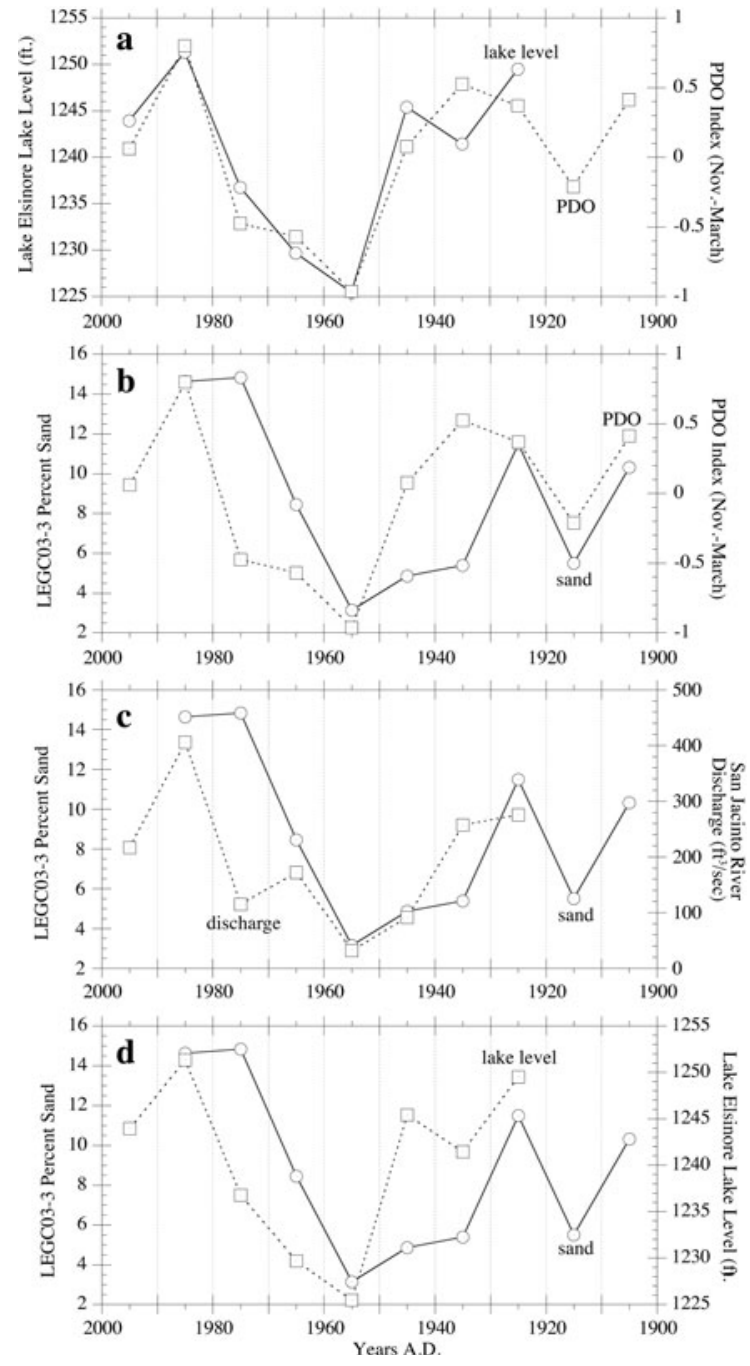

Fig. 9 Twentieth century binned data. a Lake Elsinore lake level versus PDO index. b LEGC03-3 standardized sand versus PDO index. c LEGC03-3 standardized sand versus San Jacinto River Discharge. d LEGC03-3 standardized sand versus Lake Elsinore lake level

Lake Elsinore grain size data (Fig. 10). Although not perfect, the comparison indicates that increases in sand over the interval compared correlate generally to positive PDO excursions and vice versa. Considering the difference in age control, the similarity between these two independent PDO proxies is impressive. There is, however, an off-set between the highest PDO values $c a$. AD 1480-1550 from MacDonald and Case (2005) and the peak sand values ca. 265-350 cal year BP. Interestingly, the peak sand values between 265 and 350 cal year BP correspond to a regionally (and

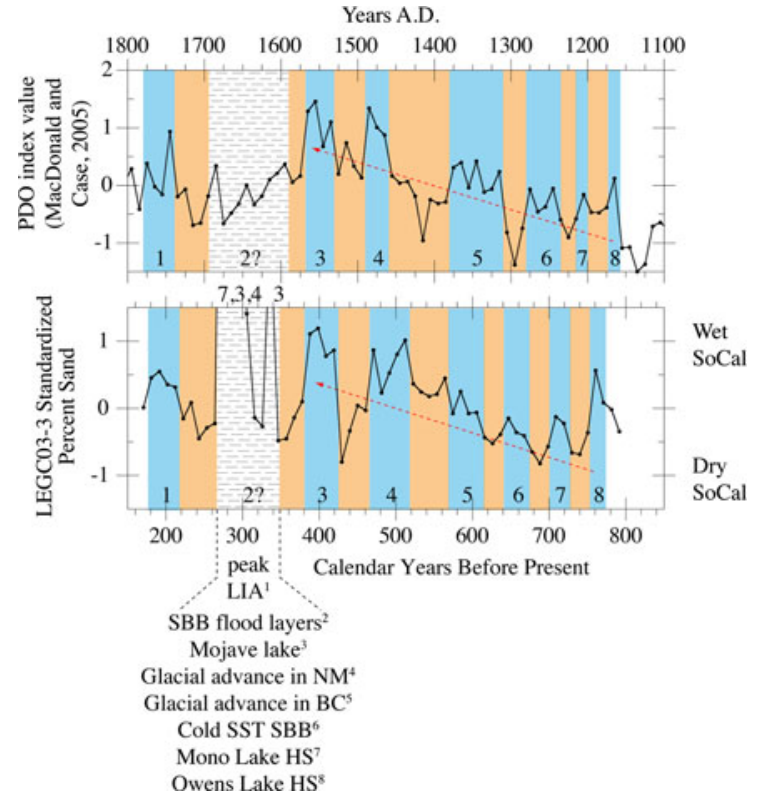

Fig. 10 Comparison of MacDonald and Case (2005) PDO reconstruction and LEGC03-3 standardized percent sand. Peak LIA (Little Ice Age) interval references include: ${ }^{1}$ Matthews and Briffa (2005), ${ }^{2}$ Schimmelmann et al. (1998), ${ }^{3}$ Enzel et al. (1992), ${ }^{4}$ Mann and Meltzer (2007), ${ }^{5}$ Allen and Smith (2007), ${ }^{6}$ Fisler and Hendy (2008), ${ }^{7}$ Stine (1990), ${ }^{8}$ Li et al. (2000). Odd numbered intervals correspond to warm (positive) PDO phases and inferred wet intervals in Southern California. Note the similar long term wetting trend from AD 1150 (800 cal year BP) to AD 1575 (400 cal year BP)

maybe western North American) wet (cool?) interval, perhaps representing the culmination of the Little Ice Age and a brief decoupling of the PDO's predominant control on regional climate (Fig. 10). A recent paper by Hunt (2008) suggests that the influence of the PDO on regional climate is not necessarily stable through time, though the reasons for this instability are not known nor has Hunt's conclusion been assessed in the paleo-record. Nonetheless, from the twentieth century and MacDonald and Case (2005) comparisons, we conclude that our sand-PDO proxy is a reliable indicator of PDO-related hydrologic variability for extrapolation over the past 10,000 years.

\section{Depositional model for grain size proxy}

Our results indicate that percent total sand, especially very fine sand, increases during twentieth century highstands (and high discharge) and decreases during lowstands (and low discharge) (Figs. 8, 9). As with 
most, if not all lake basins, Lake Elsinore is characterized by a pronounced grain size gradient from coarse grains in the littoral zone to fine grains in the profundal zone (Anderson 2001a). In most lake basins, sediment focusing is the usual explanation for this gradient (Davis and Ford 1982). Sediment focusing is a process that removes fine grain sediment from the littoral zone and re-deposits it in the profundal zone via wave action/winnowing, nearshore currents, and/or littoral migration associated with changes in lake level. Here, we present a depositional model to explain the coarse-highstand/ fine-lowstand relationship observed in Lake Elsinore using the concept of sediment focusing as an important depositional process.

Lake Elsinore lake level, as for many aridenvironment lakes, is controlled directly by the amount of precipitation (Figs. 8, 9). Yet lake level response to above average precipitation versus below average precipitation is generally asymmetric. In other words, a single large storm or above average wet year can fill Lake Elsinore, whereas, it requires several years or more of below average precipitation to lower lake level (Fig. 8). We suggest that a result of this asymmetric, gradual lowering of lake level is to enhance the process of sediment focusing $\left(\mathrm{SF}_{\mathrm{i}}\right)$ of fine grain sediments from the littoral zone into the profundal zone (Fig. 11: $\mathrm{T}_{1}-\mathrm{T}_{4}$ ). During the gradual lake level lowering, other sources of sediment such as river discharge and associated density over- and underflows $\left(\mathrm{DO}_{\mathrm{i}}+\mathrm{DU}_{\mathrm{i}}\right)$ and/or direct runoff plus overland flow $\left(\mathrm{R}_{\mathrm{i}}+\mathrm{O}_{\mathrm{i}}\right)$, which transport coarser grain sediments, are limited due to less precipitation, less direct runoff, and lower river discharge (Anderson 1977, 2001a, b; Retelle and Child 1996). The net result is to decrease the coarse grain content in the profundal sediments during intervals of below average precipitation and declining lake level while increasing the contribution of fine-grained, reworked (i.e. focused) sediments from the littoral zone into the profundal zone (Fig. 11). It is expected that eolian input $\left(E_{i}\right)$ is small relative to $\mathrm{SF}_{\mathrm{i}}, \mathrm{DO}_{\mathrm{i}}+\mathrm{DU}_{\mathrm{i}}$, and $\mathrm{R}_{\mathrm{i}}+\mathrm{O}_{\mathrm{i}}$, however, a slight increase in fine grain sediment via $E_{i}$ is likely more important during dry climates than during wet climates (Fig. 11). During above average precipitation and rising lake level, the sediment focusing process is offset by an increase in sediment transport processes such as $\mathrm{DO}_{i}+\mathrm{DU}_{\mathrm{i}}$, and $\mathrm{R}_{\mathrm{i}}+\mathrm{O}_{\mathrm{i}}$, which can transport coarser grain sediment into the profundal zone (Fig. 11: $\mathrm{T}_{5}-\mathrm{T}_{6}$ ). Other research from the greater region of California illustrates the sensitivity of the region's landscape to changes in climate. Wetter climates generate greater runoff and drier climates less runoff (Anderson 1977, 2001b; Inman and Jenkins 1999; Hunt and Wu 2004). The asymmetric hydrologic response also provides less time for lake level stagnation in the littoral zone during rapid transgression (than during slow regression) and thus less time to focus fine grained sediment into the profundal zone. This model independently explains three observations related to Lake Elsinore sediments: (1) the occasional bulk organic carbon age reversals, which probably reflect the reworking of organics into the profundal zone from elsewhere (Fig. 2), (2) the "spiky" total sand data, which may reflect the initial rise in lake level in response to an above average year, or years, in precipitation (Figs. 5, 6, 7) (Anderson 2001b), and

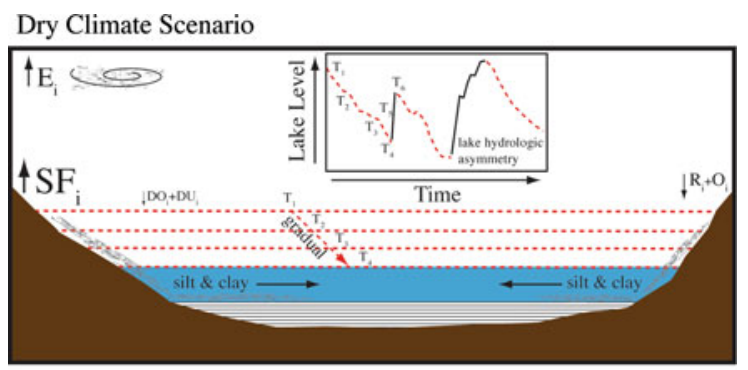

Wet Climate Scenario

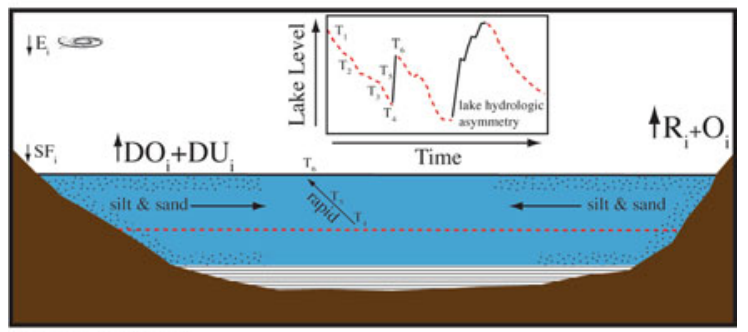

$\mathrm{E}_{\mathrm{i}}=$ eolian input

$\mathrm{SF}_{\mathrm{i}}=$ sediment focusing input

$\mathrm{R}_{\mathrm{i}}+\mathrm{O}_{i}=$ river + overland flow input

$\mathrm{DO}_{\mathrm{i}}+\mathrm{DU}_{\mathrm{i}}=$ density overflow and underflow input

Fig. 11 Proposed depositional model for the Lake Elsinore sand-climate proxy interpretation. Top panel is for a dry climate scenario and bottom panel is for a wet climate scenario. $T_{1}, T_{2}$, etc. represent times that correspond across both the schematic lake level inset and the lake level lines. Importance of the various depositional mechanisms is highlighted by font size-larger font size $=$ greater importance 
(3) the tendency for an asymmetry in the length of time between above average and below average sand content over the past 9,700 cal year BP (Fig. 7). It is expected that this model is appropriate for other shallow, arid-environment lakes, but inappropriate for temperate, deep lakes with relatively stable lake level, lake basins with a rapid depth change from the littoral to the profundal environment, and/or small catchment basins which lack a major inlet (Shuman et al. 2009).

A 10,000-year PDO-related record of hydrologic variability and regional comparisons

Figure 12 shows the 50-year binned sand data from Lake Elsinore versus a variety of regional, terrestrial paleoclimatic reconstructions. Based on the modern (i.e. past 100 years) comparison between percent sand, PDO, river discharge, and lake level, we interpret the standardized sand values greater than zero as characteristic of wetter-than-average climate, a generally positive PDO index wherein storms track more frequently across Southern California, higher regional river discharge, and high average Lake Elsinore lake level. Because we cannot create a PDO reconstruction such as that inferred with tree rings, we use the term $P D O$-related hydrologic variability. It is more realistic to assume that our proxy is capturing a component of the PDO-related system that characterizes North Pacific climate and promotes more frequent storm tracks across Southern California (Cayan and Peterson 1989; Brito-Castillo et al. 2003; Hanson et al. 2006). To help assess the multi-decadal- to centennial-scale PDO-related signal, we highlight packages of standardized sand with two or more above zero occurrences that are not separated by more than two below zero occurrences or missing data (Fig. 12). Using these criteria, nine intervals (defined as $\geq 150$ years [3 $\times 50$ year BINS]) of sustained, wet climate are recorded during the past 9,700 cal year BP: from 9,700 to $9,500,9,100$ to $8,850,6,900$ to $6,350,4,550$ to $4,100,3,700$ to $3,550,3,350$ to $3,200,1,550$ to 1,350 , 1,200 to 1,050 , and 600 to 150 calendar years before present. These intervals range from 150 to 550 years in duration. There is no apparent cyclicity or periodicity within the binned wet interval data. The early Holocene $(9,700-8,850$ cal year BP), mid-to-late Holocene (4,800-3,200 cal year BP), and latest Holocene (1,500-150 cal year BP) loosely define three generally wet intervals, though gaps in data in the latter two intervals make this claim less robust (i.e. only part of the Medieval Warm Period is present [800-600 cal year BP: no data from 1,050 to $800 \mathrm{cal}$ year BP] Fig. 12). It is possible that the purported increase in summer precipitation in the early Holocene in Southern California confounds (and conflates?) the Elsinore sand proxy (Kirby et al. 2007; Bird et al. 2010). However, the early Holocene is not unusually sandy in comparison to the other sand-rich intervals in the Elsinore record. Moreover, as previously stated, it is unlikely that summer precipitation outweighed winter precipitation in terms of total annual hydrologic budget at any time in the Holocene in southern California. As a result, it is unlikely that summer precipitation contributed significantly to river discharge and sediment transport.

The age model for LEGC03-3 is supported by two independently dated cores also from Lake Elsinorecore LESS02-5 (Kirby et al. 2004) and LEGC03-4 (Fig. 1). As shown in Kirby et al. (2004), the lake edge core LESS02-5 contains sedimentologic and isotopic evidence for a high stand centered on $c a .3,400 \mathrm{cal}$ year BP and $c a$. 1,800 cal year BP, with a period of inferred low lake level in between. The timing of this high-low-high lake level cycle fits with the LEGC03-3 sand proxy, which shows a wet climate $c a$. $3,400-3,250$, a dry climate from 3,250 to 1,850 , and brief return to a wet climate $c a$. 1,800 cal year BP (Fig. 12). Core LEGC03-4 is from a slightly shallower depth than LEGC03-3, though the depth difference between the two cores has decreased over time (0.90 m today vs. $3.80 \mathrm{~m} \mathrm{8,900} \mathrm{cal} \mathrm{year} \mathrm{BP)} \mathrm{due} \mathrm{to}$ infilling. Mudcracks in core LEGC03-4 are bracketed by dates of 3,260 and 1,710 cal year BP, indicating a period of low level at the same time as that inferred from the sand proxy in core LEGC03-3 (Fig. 12). Together, three independently dated core stratigraphies indicate a wet-dry-wet cycle $c a$. 3,400-1,700 cal year BP, which lends support to our LEGC03-3 age model, at least for the late Holocene.

Figure 13 shows the location of other terrestrial paleoclimate reconstructions from the greater region of Southern California. The proxies used for these ten reconstructions range from pollen to geochemistry to sedimentology. A comparison between the new Lake Elsinore PDO-related sand proxy and the ten regional records reveals that six out of the nine Lake Elsinore "wet" intervals correspond across $>50 \%$ of the 
Fig. 12 Comparison between Lake Elsinore binned sand data and regional sites (Fig. 13). Inferred wet intervals at Lake Elsinore are highlighted across all ten comparison sites. Wet intervals per comparison site are highlighted separately. Numbers at the top of the Elsinore sand data indicate the number of sites, including Elsinore, that are coeval to the Lake Elsinore wet intervals. Numbers with arrows exceed $50 \%$ similarity between sites

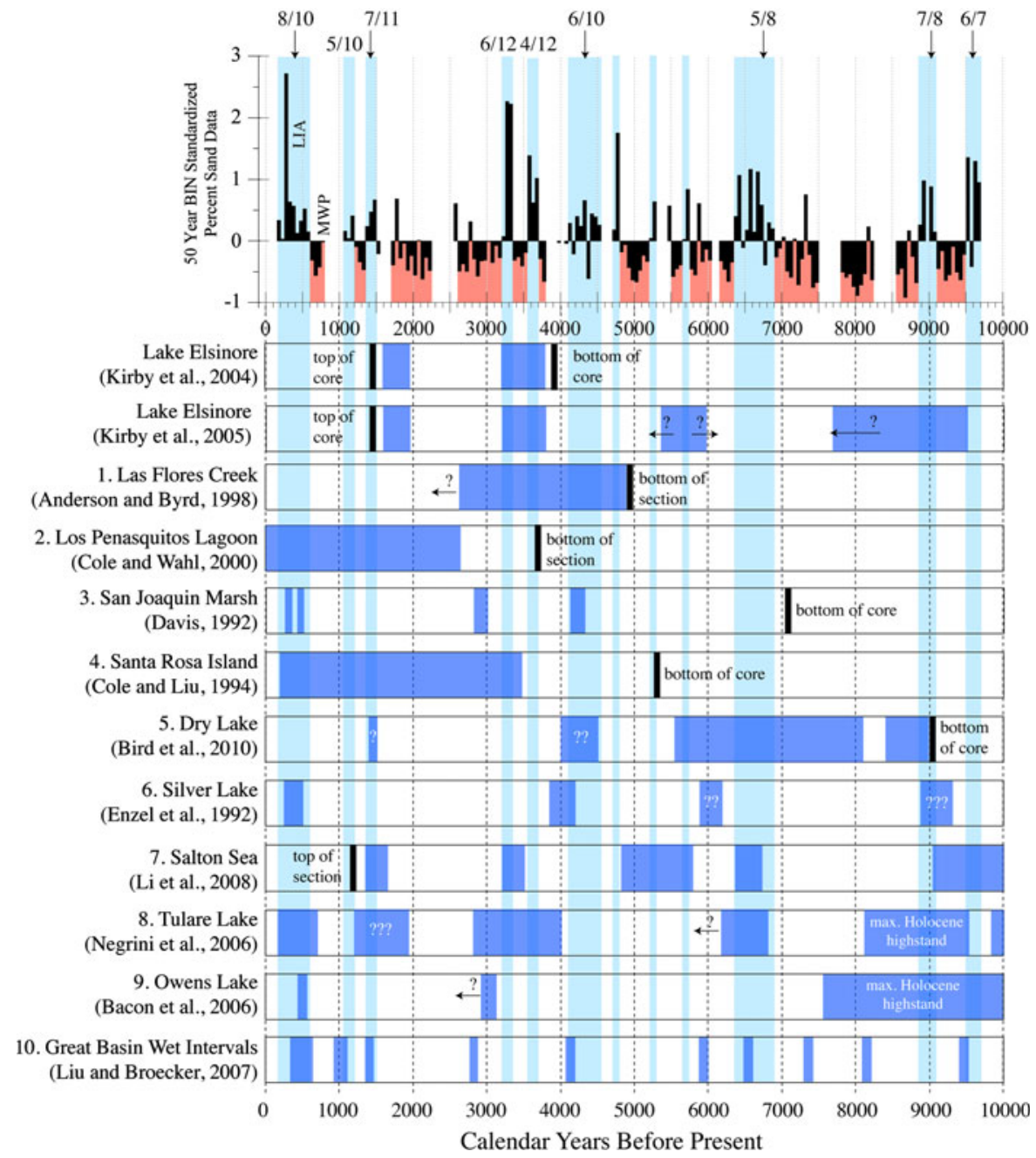

comparison sites. Obvious limitations of these comparisons include the various age controls between sites and the various types of proxies used to interpret past climate. Nonetheless, this comparison suggests that for the broader region of Southern California, there is some uniformity of climate across the region at multi-decadal to centennial intervals through the Holocene. This observation fits with the interpretation of a PDO-related control on the climate of Southern California during the Holocene. In other words, the same patterns of sea surface temperature, sea surface pressure, and thus, atmospheric circulation that increase precipitation in Southern California today were likely causing an increase in Southern California precipitation throughout the Holocene. Our results fit with those of Hanson et al. (2006) who suggest "climate variability on PDO-like time scales may have the largest influence on hydrologic time series for the basin closest to the Pacific Ocean." The effect of summer precipitation on these records, specifically the Elsinore grain size record, is likely restricted to the early Holocene and small in comparison to the much larger winter climate signal and its control on sediment distribution. Future regional GCMs are required to deconvolve the ocean-atmosphere dynamics responsible for the inferred PDO-related, multi-decadal- to centennialscale climate intervals over the Holocene, in general, and the seasonality of precipitation, specifically.

\section{A comparison to paleo-ENSO reconstructions}

It is well documented that the El Niño-Southern Oscillation (ENSO) impacts the modern weather of 
Fig. 13 Map showing comparison site locations. GBS Great Basin Sites from Liu and Broecker (2007)

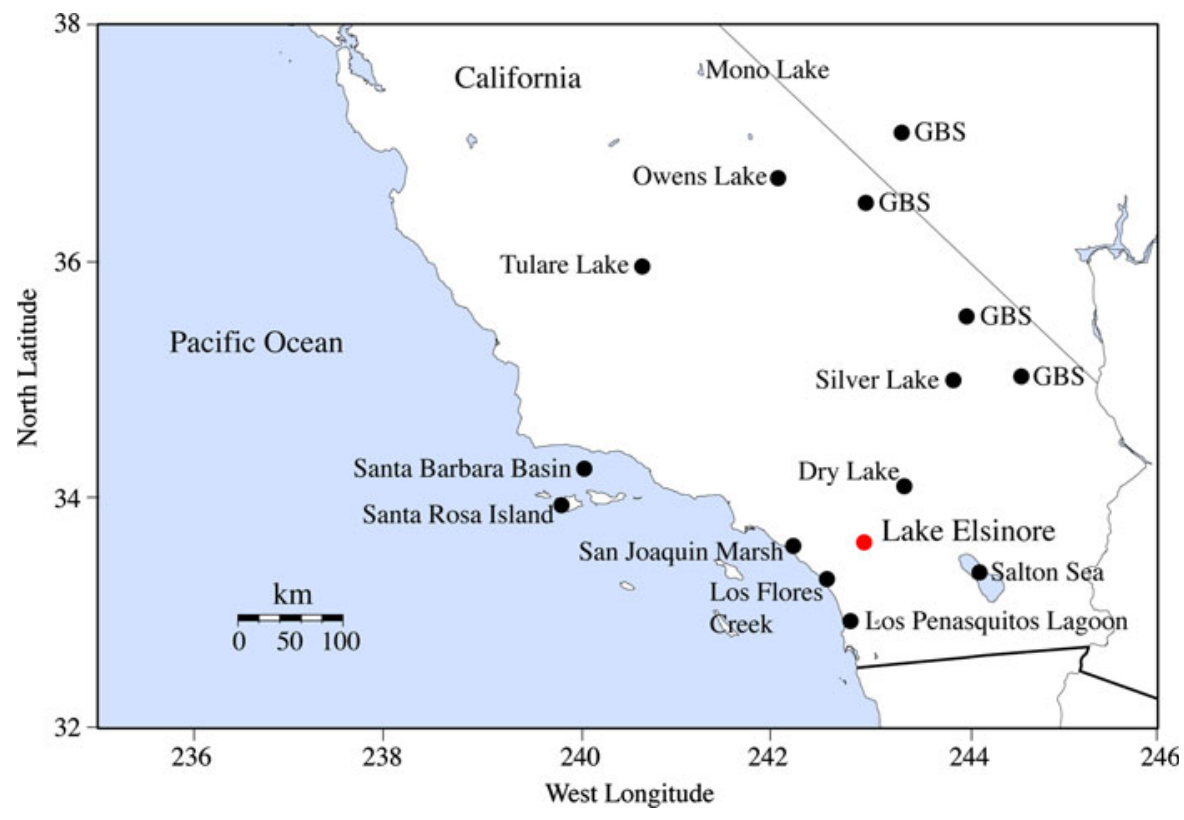

Southern California (Castello and Shelton 2004). Generally, the occurrence of El Niño increases precipitation across the southwestern United States, including our study region. Therefore, it is reasonable to compare paleo-ENSO reconstructions to the new Lake Elsinore data (Fig. 14). For comparison, we selected the Moy et al. (2002) and Conroy et al. (2008) paleo-ENSO reconstructions, which are centered on regions where the ENSO signal is robust and unequivocal. Both records use their sediment's physical properties to infer changes in the frequency of past El Niño events. Their interpretation, connecting climate to lake sediments is similar to our interpretation, i.e. an increase in storms tracking across the study site increases the contribution of coarse sediment into the lake basin (Moy et al. 2002; Conroy et al. 2008). Interestingly, our comparison to Moy et al. (2002) and Conroy et al. (2008) indicates that changes in the frequency of El Niño events is not driving the sand signal in Lake Elsinore (Fig. 14). Moreover, the characteristic increase in El Niño activity through the Holocene is not observed in the Lake Elsinore record, particularly the step-increase in activity $c a$. 3,500-4,000 cal year BP (Figs. 6, 14). In fact, the Lake Elsinore sand data indicate a decrease in storm activity in the late Holocene. Figure 6 shows the occurrence of $>1.5$ standard deviations above average sand values for the past 9,700 cal year BP in Lake Elsinore. Prior to 3,200 cal year BP, there are 41 sand spikes in the Lake Elsinore record, which are interpreted as a change in the frequency of exceptionally wet (high discharge) years and/or changes in large storm activity. After 3,200 cal year BP, there are only six sand spikes. Averaged, this change equates to a decrease from one "event" per 158 years to one event per 525 years, pre- and post-3,200 cal year BP, respectively. Of note, this decrease in exceptionally wet (high discharge) years and/or changes in large storm activity is supported by Kirby et al. (2007) who argued for a Holocene-scale drying trend forced by long-term insolation change. Perhaps most striking is the dramatic decrease in the frequency of El Niño during the Little Ice Age interval when the greater region of Southern California was almost uniformly wet (Figs. 10, 12). If changes in the frequency of El Niño events were driving the sand signal in Lake Elsinore, it is reasonable to assume that our record should look similar to the Moy et al. (2002) and the Conroy et al. (2008) records. Because of the significant differences between the latter two records and our new sand data, we conclude that changes in the frequency and occurrence of El Niño events is not the predominant forcing behind the sand signal at Lake Elsinore, at least at multi-decadal to centennial scales. Locally, Masters (2006) used Tivela shell dates to link Holocene sand beach accretion to ENSO storm activity [via the Moy et al. (2002) ENSO reconstruction] in Southern California. As expected from the Moy et al. 
Fig. 14 Comparison between Lake Elsinore 50-year binned sand data and ENSO reconstructions. Top Percent sand data from El Junco Lake in the Galapagos Islands (Conroy et al. 2008); Middle Lake Elsinore 50-year binned standardized sand data; Bottom Number of warm events (El Niño events) per 100 years from Laguna Pallcacocha in Southern Ecuador. Lake Elsinore wet intervals are highlighted across all three records

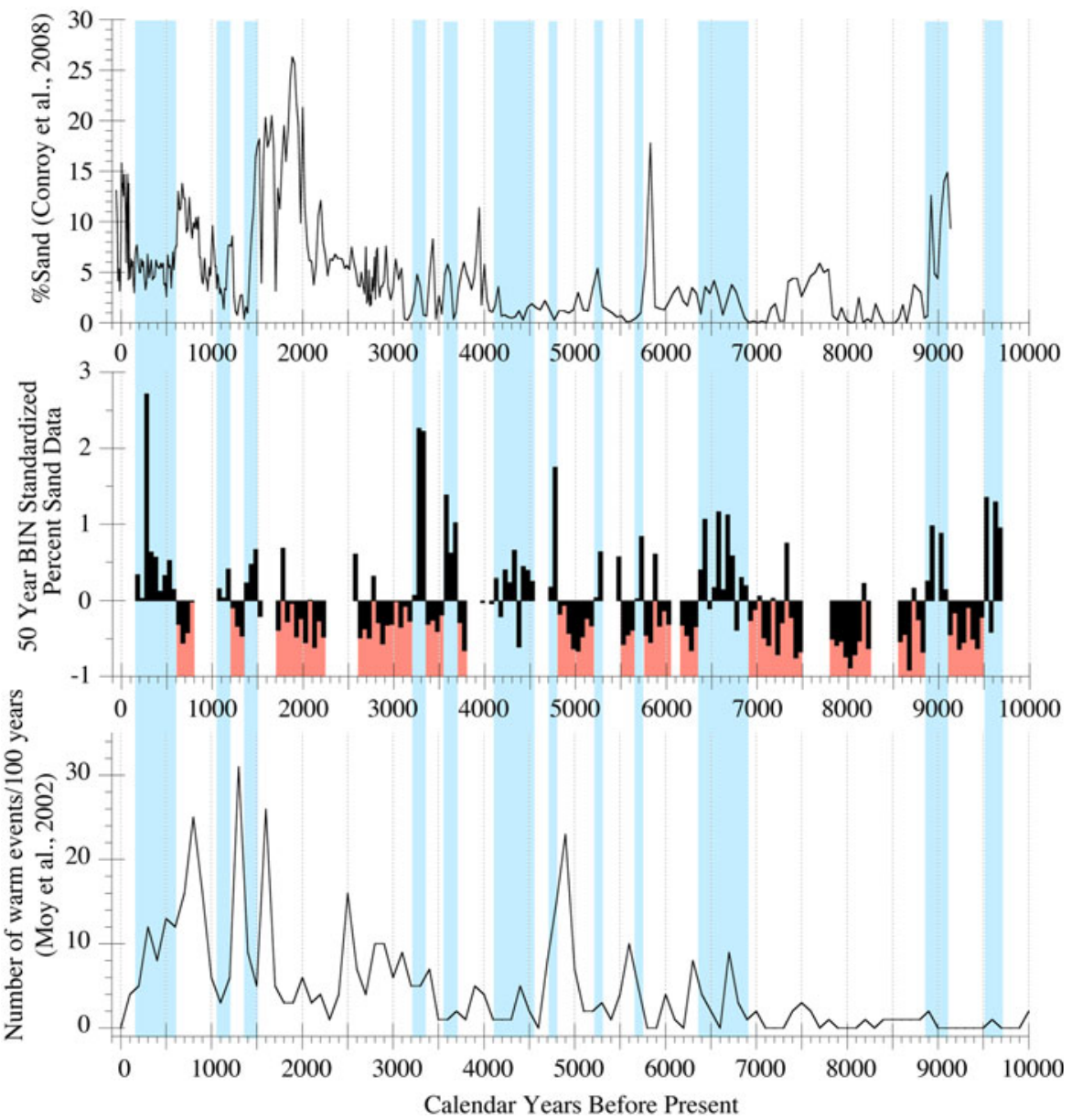

(2002) and Conroy et al. (2008) paleo-ENSO comparisons, the Elsinore grain size data do not match the Masters (2006) record.

We note that Kirby et al. (2005) used lowresolution, littoral sediment cores from Lake Elsinore to postulate the onset of modern El Niño activity in Southern California. Our new results (i.e. this paper) do not support the interpretation of Kirby et al. (2005) regarding the ENSO hypothesis. The higher-resolution, profundal sediment core data combined with the correlation between recent sand data, the PDO index, river discharge data, and Lake Elsinore lake level (Fig. 9), support a re-interpretation of the Kirby et al. (2005) data in terms of PDO-related, not ENSO, variability.

This apparent decoupling between ENSO activity and the paleo-records of Southern California, despite the modern relationship, is not entirely unexpected. Kirby et al. (2006) used sediments from Baldwin
Lake in Southern California, spanning the last glacial period to demonstrate that periods of supposed superENSO activity [i.e. preferred El Niño-like conditions (Stott et al. 2002)] were associated with lake level lowstands at Baldwin Lake and elsewhere in western North America (Benson et al. 2003). The new Lake Elsinore data seem to support the conclusions of Kirby et al. (2006) that ENSO's forcing on the climate of Southern California is decoupled at longer timescales than that captured in the modern/historical record. It remains unclear why there is a decoupling between that observed in the modern climate system and that reconstructed in the paleoclimate system for Southern California. Clearly, there is a need for additional high-resolution, terrestrial records from the region as well as focused GCM work to address this issue, which is critical to understanding present and future hydrologic variability in the over-populated, water-poor region of Southern California. 


\section{Conclusions}

New 1-cm contiguous grain size data from core LEGC03-3 provide new insights into Holocene multidecadal- to centennial-scale climate variability. Our conclusions are summarized below:

1. Percent sand, especially very fine sand, shows a strong correlation with twentieth century PDO variability, Lake Elsinore lake level, and San Jacinto River discharge. Consequently, we used percent total sand as a qualitative proxy for PDOrelated hydrologic variability over the past 9,700 cal year BP.

2. As an independent assessment of our Lake Elsinore PDO-related sand proxy, we compared our sand data to the MacDonald and Case (2005), 1,000-year PDO reconstruction. The comparison reveals excellent correlations at decadal to multidecadal time scales, with the exception of the LIA. The MacDonald and Case (2005) PDO reconstruction is weakly negative (cold PDO phase) during the peak stage of the LIA. The Elsinore PDO-related sand proxy indicates a wet climate during the peak stage of the LIA, which is supported by other evidence across western North America.

3. A depositional model is proposed to explain the coarse (fine), wet (dry) relationship observed in the twentieth century Lake Elsinore proxy calibration. The model focuses on the impact of the asymmetrical lake level changes characteristic of arid-environment lakes (i.e. rapid transgressions vs. slow regressions) on sediment depositional processes.

4. Using the PDO-related sand proxy, nine intervals of sustained wet climate are recorded during the past 9,700 cal year BP: from 9,700 to 9,500 , 9,100 to $8,850,6,900$ to $6,350,4,550$ to 4,100 , 3,700 to $3,550,3,350$ to $3,200,1,550$ to 1,350 , 1,200 to 1,050 , and 600 to 150 calendar years before present (cal year BP). A comparison between the new Lake Elsinore PDO-related sand proxy and the ten regional records reveals that six out of the nine Lake Elsinore "wet" intervals correspond across $>50 \%$ of the comparison sites. This comparison suggests that for the broader region of Southern California, there is some uniformity of climate across the region at multi-decadal to centennial intervals through the Holocene.

5. A comparison to two well known ENSO reconstructions (Moy et al. 2002; Conroy et al. 2008) shows almost no relationship between increased frequency or occurrence of El Niño over the Holocene despite the well documented impact of ENSO variability in the modern Southern California climate system. Future regional GCMs are required to explain this observation for both the lack of an ENSO signal and the presence of a PDO signal.

6. The lack of a strong ENSO signal coupled with the presence of a strong PDO signal over the past 9,700 cal year BP suggests that future predictive models should focus on the PDO for predicting decadal-scale hydrologic variability in the overpopulated, water-poor region of Southern California.

Acknowledgements This research was funded by the National Science Foundation (EAR-0602269-01) to MEK and SPL. Additional funds were provided by a Lake Elsinore-San Jacinto Water Authority (LESJWA) contract to MEK and MAA and the American Chemical Society-Petroleum Research Fund (ACS-PRF: Grant \#41789-GB8) to MEK. Funds from Cal-State Fullerton Faculty-Student Creative Research Grants provided summer stipends for several students. Special thanks to the City of Lake Elsinore, particularly Mr. Patrick Kilroy (Lake Manager) for access to the lake; Mr. David Ruhl (LESJWA) for contract management; Gregg Drilling and Testing, Inc. for exceptional quality service; Drs. John Southon and Guaciara dos Santos (Univ. of Cal. Irvine) for radiocarbon dating; Dr. James Noblet (CSUSB) and his students for modern limnological data; and Ms. Jennifer Schmidt for careful lab analyses. Excellent reviews by two anonymous referees helped improve the paper's content and clarity.

Open Access This article is distributed under the terms of the Creative Commons Attribution Noncommercial License which permits any noncommercial use, distribution, and reproduction in any medium, provided the original author(s) and source are credited.

\section{References}

Adams DK, Comrie AC (1997) The North American monsoon. Bull Am Met Soc 78:2197-2213

Allen SM, Smith DJ (2007) Late Holocene glacial activity of Bridge Glacier, British Columbia Coast Mountains. Can J Ear Sci 44:1753-1773

Anderson RY (1977) Short-term sedimentation response in lakes in western United States as measured by automated sampling. Limnol Oceanogr 22:423-433 
Anderson MA (2001a) Internal loading and nutrient cycling in Lake Elsinore. Santa Ana Regional Water Quality Control Board, Lake Elsinore, p 52

Anderson RY (2001b) Rapid changes in Late Pleistocene precipitation and stream discharge determined from medium- and coarse-grained sediment in saline lakes. Glob Plan Chan 28:73-83

Anderson RS, Byrd BF (1998) Late-Holocene vegetation changes from the Las Flores Creek coastal lowlands, San Diego County, California. Madrono 45:171-182

Bacon SN, Burke RM, Pezzopane SK, Jayko AS (2006) Last glacial maximum and Holocene lake levels of Owens Lake, eastern California, USA. Quat Sci Rev 25: 1264-1282

Barnett TP, Pierce DW, Hidalgo HG, Bonfils C, Santer BD, Das T, Bala G, Wood AW, Nozawa T, Mirin AA, Cayan DR, Dettinger MD (2008) Human-induced changes in the hydrology of the western United States. Science 319:1080-1083

Benson LV, Meyers PA, Spencer RJ (1991) Change in the size of Walker Lake during the past 5000 years. Palaeogeogr Palaeoclimatol Palaeoecol 81:189-214

Benson L, Lund S, Negrini R, Linsley B, Zic M (2003) Response of North America Great Basin Lakes to Dansgaard-Oeschger oscillations. Quat Sci Rev 22:2239-2251

Berry WL, MacRostie W, Sabiston DW (1953) Elsinore Basin investigation. State Water Resources Board, Sacramento, p 105

Beuhler M (2003) Potential impacts of global warming on water resources in southern California. Water Sci Technol 47:165-168

Bird BW, Kirby ME, Howat IM, Tulaczyk S (2010) Geophysical evidence for Holocene lake-level change in southern California (Dry Lake). Boreas 39:131-144

Brito-Castillo L, Douglas AV, Leyva-Contreras A, LluchBelda D (2003) The effect of large-scale circulation on precipitation and streamflow in the Gulf of California continental watershed. Int J Clim 23:751-768

Castello AF, Shelton ML (2004) Winter precipitation on the US Pacific coast and El Nino-Southern Oscillation events. Int J Clim 24:481-497

Cayan DR, Peterson DH (1989) The influence of North Pacific atmospheric circulation on streamflow in the west in aspects of climate variability in the Pacific and the western Americas. In: AGU (ed) Geophysical monograph series, American Geophysical Union, Washington, pp 375-397

CDWR (2005) California Water Plan Update 2005

Cole KL, Liu GW (1994) Holocene paleoecology of an estuary on Santa Rosa Island, California. Quat Res 41:326-335

Cole KL, Wahl E (2000) A late Holocene paleoecological record from Torrey Pines State Reserve, California. Quat Res 53:341-351

Collins DBG, Bras RL (2008) Climatic control of sediment yield in dry lands following climate and land cover change. Water Resour Res 44:W10405

Conroy JL, Overpeck JT, Cole JE, Shanahan TM, SteinitzKannan M (2008) Holocene changes in eastern tropical Pacific climate inferred from a Galapagos lake sediment record. Quat Sci Rev 27:1166-1180
Davis OK (1992) Rapid climatic change in coastal southern California inferred from pollen analysis of San Joaquin Marsh. Quat Res 37:89-100

Davis MB, Ford MS (1982) Sediment focusing in Mirror Lake, New Hampshire. Limnol Oceanogr 27:137-150

Dearing JA (1991) Lake sediment records of erosional processes. Hydrobiologia 214:99-106

Enzel Y, Brown WJ, Anderson RY, McFadden LD, Wells SG (1992) Short-duration Holocene lakes in the Mojave River drainage basin, Southern California. Quat Res 38:60-73

Fisler J, Hendy IL (2008) California current system response to late Holocene climate cooling in southern California. Geo Res Lett 35:L09702. doi:10.1029/2008GL033902

Hanson R, Dettinger M, Newhouse M (2006) Relations between climatic variability and hydrologic time series from four alluvial basins across the southwestern United States. Hyd J 14:1122-1146

Hull AG (1990) Seismotectonics of the Elsinore-Temecula Trough, Elsinore Fault Zone, Southern California. Geological Sciences. UC Santa Barbara, Santa Barbara, p 233

Hunt B (2008) Secular variation of the Pacific Decadal Oscillation, the North Pacific Oscillation and climatic jumps in a multi-millennial simulation. Clim Dyn 30:467-483

Hunt AG, Wu JQ (2004) Climatic influences on Holocene variations in soil erosion rates on a small hill in the Mojave Desert. Geomorphology 58:263-289

Inman DL, Jenkins SA (1999) Climate change and the episodicity of sediment flux of small California Rivers. J Geo 107:251-270

Kirby ME, Poulsen CJ, Lund SP, Patterson WP, Reidy L, Hammond DE (2004) Late Holocene lake-level dynamics inferred from magnetic susceptibility and stable oxygen isotope data: Lake Elsinore, Southern California (USA). J Paleolimnol 31:275-293

Kirby ME, Lund SP, Poulsen CJ (2005) Hydrologic variability and the onset of modern El Nino-Southern Oscillation: a 19 250-year record from Lake Elsinore, southern California. J Quat Sci 20:239-254

Kirby ME, Lund SP, Bird BW (2006) Mid-Wisconsin sediment record from Baldwin Lake reveals hemispheric climate dynamics (Southern CA, USA). Palaeogeogr Palaeoclimatol Palaeoecol 241:267-283

Kirby M, Lund S, Anderson M, Bird B (2007) Insolation forcing of Holocene climate change in Southern California: a sediment study from Lake Elsinore. J Paleolimnol 38:395-417

Li HC, Stott LD, Bischoff JL, Ku T-L, Lund SP (2000) Climate variability in East-Central California during the past 1000 years reflected by high-resolution geochemical and isotopic records from Owens Lake sediments. Quat Res 54:189-197

Li HC, Xu XM, Ku TL, You CF, Buchheim HP, Peters R (2008) Isotopic and geochemical evidence of palaeoclimate changes in Salton Basin, California, during the past 20 kyr: 1. [delta] 180 and [delta]13C records in lake tufa deposits. Palaeogeogr Palaeoclimatol Palaeoecol 259:182-197

Liu T, Broecker WS (2007) Holocene rock varnish microstratigraphy and its chronometric application in the drylands of western USA. Geomorphology 84:1-21 
Macdonald GM, Case RA (2005) Variations in the Pacific Decadal Oscillation over the past millennium. Geo Res Lett 32:L08703. doi:10.1029/2005GL022478

Malvern Instruments (1999) Operators guide. Malvern Instruments, Worcestershire

Mann DH, Meltzer DJ (2007) Millennial-scale dynamics of valley fills over the past $12,00014 \mathrm{C}$ yr in northeastern New Mexico, USA. Geo Soc Am Bull 119:1433-1448

Mantua NJ, Francis RC, Hare SR, Zhang Y, Wallace JM (1997) A Pacific interdecadal climate oscillation with impacts on salmon production. Bull Am Met Soc 78:1069-1079

Masters PM (2006) Holocene sand beaches of southern California: ENSO forcing and coastal processes on millennial scales. Palaeogeogr Palaeoclimatol Palaeoecol 232:73-95

Matthews JA, Briffa KR (2005) The 'Little Ice Age': re-evaluation of an evolving concept. Geo Ann Series A Phy Geo 87:17-36

Mensing S, Byrne R (1998) Pre-mission invasion of Erodium cicutarium in California. J Biogeogr 25:757-762

Moy CM, Seltzer GO, Rodbell DT, Anderson DM (2002) Variability of El Niño/Southern Oscillation activity at millennial timescales during the Holocene epoch. Nature 420:162-165

Negrini RM, Wigand PE, Draucker S, Gobalet K, Gardner JK, Sutton MQ, Yoheli RM (2006) The Rambla highstand shoreline and the Holocene lake-level history of Tulare Lake, California, USA. Quat Sci Rev 25:1599-1618

Parris A, Bierman P, Noren A, Prins M, Lini A (2010) Holocene paleostorms identified by particle size signatures in lake sediments from the northeastern United States. J Paleolimnol 43:29-49

Retelle MJ, Child JK (1996) Suspended sediment transport and deposition in a high arctic meromictic lake. J Paleolimnol 16:151-167
Schimmelmann A, Zhao M, Harvey CC, Lange CB (1998) A large California flood and correlative global climatic events 400 years ago. Quat Res 49:51-61

Seager R, Ting M, Held I, Kushnir Y, Lu J, Vecchi G, Huang HP, Harnik N, Leetmaa A, Lau NC, Li C, Velez J, Naik N (2007) Model projections of an imminent transition to a more arid climate in Southwestern North America. Science 316:1181-1184

Shuman B, Henderson AK, Colman SM, Stone JR, Fritz SC, Stevens LR, Power MJ, Whitlock C (2009) Holocene lake-level trends in the Rocky Mountains. U.S.A. Quat Sci Rev 28:1861-1879

Stine S (1990) Late Holocene fluctuations of Mono Lake, eastern California. Palaeogeogr Palaeoclimatol Palaeoecol 78:333-381

Stott L, Poulsen C, Lund S, Thunell R (2002) Super ENSO and global climate oscillations at millennial time scales. Science 297:222-226

Stuiver M, Reimer PJ (1993) Extended 14C database and revised CALIB radiocarbon calibration program. Radiocarbon 35:215-230

Swartz R, Hauge C (2003) California groundwater-2003 update, CA Department Water Resources, Bulletin 118, p 246

Trenberth KB, Hurrell JW (1994) Decadal atmosphere-ocean variations in the Pacific. Clim Dyn 9:303-319

Tubbs AM (1972) Summer thunderstorms over Southern California. Mon Wea Rev 100:799-807

Williams J (2005) Background: California's tropical storms. USA Today, Los Angeles

Wise EK (2010) Spatiotemporal variability of the precipitation dipole transition zone in the western United States. Geo Res Lett 37:L07706

Yair A, Kossovsky A (2002) Climate and surface properties: hydrological response of small arid and semi-arid watersheds. Geomorphology 42:43-57 